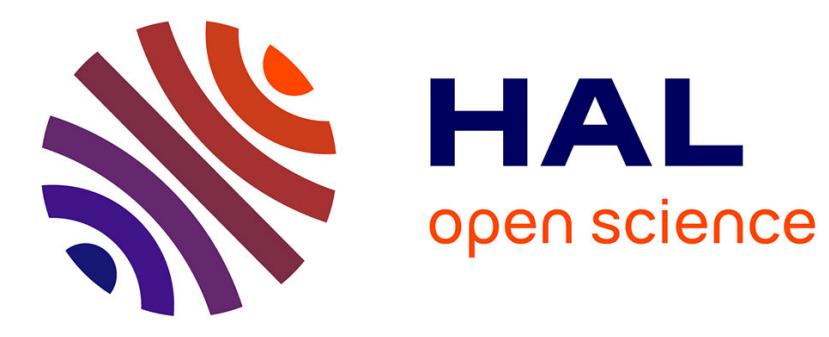

\title{
Chiroptical study of cryptophanes subjected to self-encapsulation
}

Orsola Baydoun, Thierry Buffeteau, Nicolas Daugey, Marion Jean, Nicolas Vanthuyne, Laure-lise Chapellet, Nicolas de Rycke, Thierry Brotin

\section{- To cite this version:}

Orsola Baydoun, Thierry Buffeteau, Nicolas Daugey, Marion Jean, Nicolas Vanthuyne, et al.. Chiroptical study of cryptophanes subjected to self-encapsulation. Chirality, 2019, 10.1002/chir.23079 . hal-02141856

\section{HAL Id: hal-02141856 https://hal.science/hal-02141856}

Submitted on 20 Mar 2020

HAL is a multi-disciplinary open access archive for the deposit and dissemination of scientific research documents, whether they are published or not. The documents may come from teaching and research institutions in France or abroad, or from public or private research centers.
L'archive ouverte pluridisciplinaire HAL, est destinée au dépôt et à la diffusion de documents scientifiques de niveau recherche, publiés ou non, émanant des établissements d'enseignement et de recherche français ou étrangers, des laboratoires publics ou privés. 


\section{Chiroptical Study of Cryptophanes Subjected to Self-Encapsulation}

Orsola Baydoun, ${ }^{\dagger}$ Thierry Buffeteau ${ }^{*, \neq}$ Nicolas Daugey, ${ }^{\ddagger}$ Marion Jean,,$^{\S}$ Nicolas Vanthuyne, ${ }^{\S}$ Laure-Lise Chapellet, ${ }^{\dagger}$ Nicolas De Rycke ${ }^{\dagger}$ and Thierry Brotin, ${ }^{*}{ }^{\dagger}$

${ }^{\dagger}$ Lyon 1 University, Ecole Normale Supérieure de Lyon, CNRS UMR 5182, Laboratoire de Chimie, 69364 Lyon, France

${ }^{\ddagger}$ Bordeaux University, Institut des Sciences Moléculaires, CNRS UMR 5255, 33405 Talence, France

${ }^{\S}$ Aix-Marseille University, CNRS, Centrale Marseille, iSm2, Marseille, France

e-mail: thierry.buffeteau@u-bordeaux.fr; thierry.brotin@ens-lyon.fr 


\section{Table of contents :}

Figure S1: Chromatograms (Chiralpak IC, 250 x $4.6 \mathrm{~mm}$, heptane/ethanol/ $\mathrm{CH}_{2} \mathrm{Cl}_{2}$ : 50/10/40, $1 \mathrm{~mL} / \mathrm{min}$ at $25{ }^{\circ} \mathrm{C}$ ) of the (rac)-1 before preparative separation on Chiralpak IC ( $250 \mathrm{x} 10$ $\mathrm{mm}$, heptane/ethanol/ $\mathrm{CH}_{2} \mathrm{Cl}_{2}$ : 50/10/40, $5 \mathrm{~mL} / \mathrm{min}$ ).

Figure S2: Chromatograms (Chiralpak IC, 250 x $4.6 \mathrm{~mm}$, heptane/ethanol/ $\mathrm{CH}_{2} \mathrm{Cl}_{2}: 50 / 10 / 40$, $1 \mathrm{~mL} / \mathrm{min}$ at $25{ }^{\circ} \mathrm{C}$ ) of the collected $\left[\mathrm{CD}(-)_{254}\right]-\mathbf{1}$ and $\left[\mathrm{CD}(+)_{254}\right]-\mathbf{1}$ after preparative separation on Chiralpak IC (250 x $10 \mathrm{~mm}$, heptane/ethanol/ $\left.\mathrm{CH}_{2} \mathrm{Cl}_{2}: 50 / 10 / 40,5 \mathrm{~mL} / \mathrm{min}\right)$. Detection performed by UV-Vis spectroscopy at $230 \mathrm{~nm}$ (black chromatograms) and CD spectroscopy at $254 \mathrm{~nm}$ (red chromatograms).

Figure S3: Experimental procedure for the synthesis of cryptophane 2.

Figure S4: Experimental procedure for the synthesis of cryptophane 3.

Figure S5: Chromatograms ((S,S)-Whelk- $\mathrm{O}_{1}, 250$ x $4.6 \mathrm{~mm}$, heptane/ethanol/ $\mathrm{CH}_{2} \mathrm{Cl}_{2}$ : 20/40/40, $1 \mathrm{~mL} / \mathrm{min}$ at $25^{\circ} \mathrm{C}$ ) of the (rac)-2 before preparative separation on $(S, S)$-Whelk-O (250 x $10 \mathrm{~mm}$, heptane/ethanol/ $\mathrm{CH}_{2} \mathrm{Cl}_{2}:$ 20/40/40, $5 \mathrm{~mL} / \mathrm{min}$ ).

Figure S6: Chromatograms $\left((S, S)-\right.$ Whelk- $\mathrm{O}_{1}, 250$ x $4.6 \mathrm{~mm}$, heptane/ethanol/ $\mathrm{CH}_{2} \mathrm{Cl}_{2}$ : 20/40/40, $1 \mathrm{~mL} / \mathrm{min}$ at $25^{\circ} \mathrm{C}$ ) of the collected $\left[\mathrm{CD}(-)_{254}\right]-2$ and $\left[\mathrm{CD}(+)_{254}\right]-2$ after preparative separation on $(S, S)$-Whelk-O ${ }_{1}\left(250 \times 10 \mathrm{~mm}\right.$, heptane/ethanol/ $\left.\mathrm{CH}_{2} \mathrm{Cl}_{2}: 20 / 40 / 40,5 \mathrm{~mL} / \mathrm{min}\right)$. Detection performed by UV-Vis spectroscopy at $230 \mathrm{~nm}$ (black chromatograms) and CD spectroscopy at $254 \mathrm{~nm}$ (red chromatograms).

Figure S7: Chromatograms ((S,S)-Whelk- $\mathrm{O}_{1}, 250 \times 4.6 \mathrm{~mm}$, ethanol/ $\mathrm{CH}_{2} \mathrm{Cl}_{2}$ : 50/50, 1 $\mathrm{mL} / \mathrm{min}$ at $\left.25{ }^{\circ} \mathrm{C}\right)$ of the (rac)-3 before preparative separation on $(S, S)$-Whelk-O ${ }_{1}(250 \times 10$ $\mathrm{mm}$, heptane/ethanol/ $\left.\mathrm{CH}_{2} \mathrm{Cl}_{2}: 35 / 65,5 \mathrm{~mL} / \mathrm{min}\right)$.

Figure S8: Chromatograms ((S,S)-Whelk- $\mathrm{O}_{1}, 250 \times 4.6 \mathrm{~mm}$, ethanol/ $\mathrm{CH}_{2} \mathrm{Cl}_{2}$ : 50/50, 1 $\mathrm{mL} / \mathrm{min}$ at $25{ }^{\circ} \mathrm{C}$ ) of the collected $\left[\mathrm{CD}(-)_{254}\right]-3$ and $\left[\mathrm{CD}(+)_{254}\right]-3$ after preparative separation on $(S, S)-W h e l k-\mathrm{O}_{1}\left(250 \times 10 \mathrm{~mm}\right.$, ethanol/ $\left.\mathrm{CH}_{2} \mathrm{Cl}_{2}: 50 / 50,5 \mathrm{~mL} / \mathrm{min}\right)$. Detection performed by UV-Vis spectroscopy at $230 \mathrm{~nm}$ (black chromatograms) and CD spectroscopy at $254 \mathrm{~nm}$ (red chromatograms).

Figure S9: ${ }^{1} \mathrm{H}$ NMR spectrum (300 MHz) of (rac)-1 recorded in $\mathrm{CD}_{2} \mathrm{Cl}_{2}$ at $25{ }^{\circ} \mathrm{C}$. The letters A,B,C,D,E show protons signals related to the imploded form.

Figure S10: ${ }^{1} \mathrm{H}$ NMR spectrum (300 MHz) of (rac)-1 recorded in $\mathrm{CDCl}_{3}$ at $25{ }^{\circ} \mathrm{C}$. The letters A,B,C,D show protons signals related to the imploded form.

Figure S11: ${ }^{1} \mathrm{H}$ NMR spectrum $\left(300 \mathrm{MHz}\right.$ ) of (rac)-1 recorded in DMSO- $d_{6}$ at $25{ }^{\circ} \mathrm{C}$.

Figure S12: ${ }^{1} \mathrm{H}$ NMR spectrum (300 MHz) of (rac)-1 recorded in 1,1,2,2-tetrachloroethane- $d_{2}$ at $25^{\circ} \mathrm{C}$.

Figure S13: ${ }^{1} \mathrm{H}$ NMR spectrum (300 MHz) of (rac)-2 recorded in $\mathrm{CD}_{2} \mathrm{Cl}_{2}$ at $25{ }^{\circ} \mathrm{C}$. 
Figure S14: ${ }^{1} \mathrm{H}$ NMR spectrum (300 MHz) of (rac)-2 recorded in $\mathrm{CDCl}_{3}$ at $25{ }^{\circ} \mathrm{C}$.

Figure S15: ${ }^{1} \mathrm{H}$ NMR spectrum (300 MHz) of (rac)-2 recorded in 1,1,2,2-tetrachloroethane- $d_{2}$ at $25^{\circ} \mathrm{C}$.

Figure S16: ${ }^{1} \mathrm{H}$ NMR spectrum (300 MHz) of (rac)-2 recorded in benzene- $d_{6}$ at $25{ }^{\circ} \mathrm{C}$.

Figure S17: Specific Optical Rotation (SOR) values measured for $\left[\mathrm{CD}(+)_{254}\right]-\mathbf{1}$ and [CD(-) 254 ]-1 in $\mathrm{CH}_{2} \mathrm{Cl}_{2}$ (black), $\mathrm{CHCl}_{3}$ (orange), DMSO (blue) and $\mathrm{C}_{2} \mathrm{H}_{2} \mathrm{Cl}_{4}$ (red) at $25{ }^{\circ} \mathrm{C}$. Plot of the SOR $\left(10^{-1} \mathrm{deg} \mathrm{cm}^{2} \mathrm{~g}^{-1}\right)$ values versus $\lambda(\mathrm{nm})$ for the $\left[\mathrm{CD}(+)_{254}\right]-\mathbf{1}$ enantiomer.

Figure S18: Specific Optical Rotation (SOR) values measured for $\left[\mathrm{CD}(+)_{254}\right]-2$ and [CD(-) 254 ]-2 in $\mathrm{CH}_{2} \mathrm{Cl}_{2}$ (black), $\mathrm{CHCl}_{3}$ (orange), DMSO (blue) and $\mathrm{C}_{2} \mathrm{H}_{2} \mathrm{Cl}_{4}$ (red) at $25{ }^{\circ} \mathrm{C}$. Plot of the SOR $\left(10^{-1} \mathrm{deg} \mathrm{cm}^{2} \mathrm{~g}^{-1}\right)$ values versus $\lambda(\mathrm{nm})$ for the $\left[\mathrm{CD}(+)_{254}\right]-2$ enantiomer.

Figure S19: Specific Optical Rotation (SOR) values measured for $\left[\mathrm{CD}(+)_{254}\right]-3$ and [CD(-) 254 ]-3 in $\mathrm{CH}_{2} \mathrm{Cl}_{2}$ (black), $\mathrm{CHCl}_{3}$ (orange), DMSO (blue) and $\mathrm{C}_{2} \mathrm{H}_{2} \mathrm{Cl}_{4}$ (red) at $25{ }^{\circ} \mathrm{C}$.

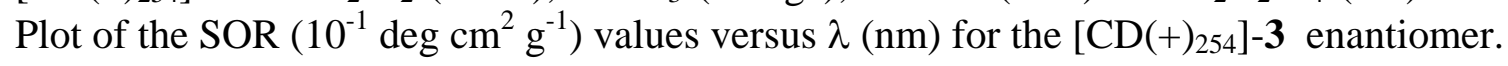

Figure S20: ECD spectra of $\left[\mathrm{CD}(+)_{254}\right]-\mathbf{1}$ (black spectra) and $\left[\mathrm{CD}(-)_{254}\right]-\mathbf{1}$ (red spectra) recorded in $\mathrm{CH}_{2} \mathrm{Cl}_{2}, \mathrm{CHCl}_{3}$, THF, $\mathrm{CH}_{3} \mathrm{CN}$, DMSO and $\mathrm{C}_{2} \mathrm{H}_{2} \mathrm{Cl}_{4}$ at $20^{\circ} \mathrm{C}$. $\left(\mathrm{c}=10^{-4}-10^{-5} \mathrm{M}\right)$. $\mathrm{UV}$-visible spectrum of 1 recorded in THF at $25^{\circ} \mathrm{C}\left(\mathrm{c}=1.1210^{-5} \mathrm{M}\right)$.

Figure S21: ECD spectra of $\left[\mathrm{CD}(+)_{254}\right]-2$ (black spectra) and $\left[\mathrm{CD}(-)_{254}\right]-2$ (red spectra) recorded in $\mathrm{CH}_{2} \mathrm{Cl}_{2}, \mathrm{CHCl}_{3}$, THF, $\mathrm{CH}_{3} \mathrm{CN}$, DMSO and $\mathrm{C}_{2} \mathrm{H}_{2} \mathrm{Cl}_{4}$ at $20^{\circ} \mathrm{C}$. $\left(\mathrm{c}=10^{-4}-10^{-5} \mathrm{M}\right)$. $\mathrm{UV}$-visible spectrum of 2 recorded in THF at $25^{\circ} \mathrm{C}\left(\mathrm{c}=1.0210^{-5} \mathrm{M}\right)$.

Figure S22: ECD spectra of $\left[\mathrm{CD}(+)_{254}\right]-3$ (black spectra) and $\left[\mathrm{CD}(-)_{254}\right]-3$ (red spectra) recorded in $\mathrm{CH}_{2} \mathrm{Cl}_{2}, \mathrm{CHCl}_{3}$, THF, $\mathrm{CH}_{3} \mathrm{CN}$, DMSO and $\mathrm{C}_{2} \mathrm{H}_{2} \mathrm{Cl}_{4}$ at $20^{\circ} \mathrm{C}$. (c $\left.=10^{-4}-10^{-5} \mathrm{M}\right)$. $\mathrm{UV}$-visible spectrum of 3 recorded in THF at $25^{\circ} \mathrm{C}\left(\mathrm{c}=0.9910^{-5} \mathrm{M}\right)$.

Figure S23: IR spectra of a) $\left[\mathrm{CD}(+)_{254}\right]-1$, b) $\left[\mathrm{CD}(+)_{254}\right]-2$ and $\left[\mathrm{CD}(+)_{254}\right]-3$ c) in $\mathrm{CDCl}_{3}$ (black spectra), $\mathrm{CD}_{2} \mathrm{Cl}_{2}$ (red spectra) and $\mathrm{C}_{2} \mathrm{D}_{2} \mathrm{Cl}_{4}$ (blue spectra) solvents $(0.015 \mathrm{mM}, 250 \mu \mathrm{m}$ path length).

Figure S24: VCD spectra of [CD(+ $\left.)_{254}\right]-1$ (black spectra) and [CD(-) 254$]-1$ (red spectra) in a) $\mathrm{CDCl}_{3}$, b) $\mathrm{CD}_{2} \mathrm{Cl}_{2}$, and c) $\mathrm{C}_{2} \mathrm{D}_{2} \mathrm{Cl}_{4}$ solvents $(0.015 \mathrm{mM}, 250 \mu \mathrm{m}$ path length).

Figure S25: VCD spectra of [CD $\left.(+)_{254}\right]-2$ (black spectra) and [CD(-) 254$]-2$ (red spectra) in a) $\mathrm{CDCl}_{3}$, b) $\mathrm{CD}_{2} \mathrm{Cl}_{2}$, and c) $\mathrm{C}_{2} \mathrm{D}_{2} \mathrm{Cl}_{4}$ solvents $(0.015 \mathrm{mM}, 250 \mu \mathrm{m}$ path length).

Figure S26: VCD spectra of [CD(+) 254$]-3$ (black spectra) and [CD $\left.(-)_{254}\right]-3$ (red spectra) in a) $\mathrm{CD}_{2} \mathrm{Cl}_{2}$ and b) $\mathrm{C}_{2} \mathrm{D}_{2} \mathrm{Cl}_{4}$ solvents $(0.015 \mathrm{mM}, 250 \mu \mathrm{m}$ path length).

Figure S27: Optimized geometry of $P P-1$ enantiomer calculated at the density functional theory (DFT) level using B3LYP functional and 6-31G** basis set with the use of IEFPCM model of solvent (IEFPCM $=\mathrm{CH}_{2} \mathrm{Cl}_{2}$ and $\mathrm{C}_{2} \mathrm{H}_{2} \mathrm{Cl}_{4}$ ). 
Figure S28: Optimized geometry of $M M-2$ enantiomer calculated at the density functional theory (DFT) level using B3LYP functional and 6-31G** basis set with the use of IEFPCM model of solvent (IEFPCM $=\mathrm{CH}_{2} \mathrm{Cl}_{2}$ and $\mathrm{C}_{2} \mathrm{H}_{2} \mathrm{Cl}_{4}$ ).

Figure S29: Comparison of experimental VCD spectrum of $\left[\mathrm{CD}(-)_{254}\right]-2$ in $\mathrm{C}_{2} \mathrm{D}_{2} \mathrm{Cl}_{4}$ solution (15 mM, $250 \mu \mathrm{m}$ path length) and VCD spectra of $M M-2$ calculated at the B3LYP/6-31G** level (IEFPCM $=\mathrm{C}_{2} \mathrm{H}_{2} \mathrm{Cl}_{4}$ ) for the trans and gauche-gauche conformations of the ethylenedioxy and propylenedioxy linkers, respectively, and for the acetate group grafted on the propylenedioxy linker pointing inside (blue spectrum) or outside (red spectrum) the cavity.

Table S1: Specific optical rotation values measured for $\left[\mathrm{CD}(+)_{254}\right]-\mathbf{1}$ in different solvents at $25{ }^{\circ} \mathrm{C}$.

Table S2: Specific optical rotation values measured for $\left[\mathrm{CD}(-)_{254}\right]-\mathbf{1}$ in different solvents at $25{ }^{\circ} \mathrm{C}$.

Table S3: Specific optical rotation values measured for $\left[\mathrm{CD}(+)_{254}\right]-2$ in different solvents at $25{ }^{\circ} \mathrm{C}$.

Table S4: Specific optical rotation values measured for $\left[\mathrm{CD}(-)_{254}\right]-2$ in different solvents at $25{ }^{\circ} \mathrm{C}$.

Table S5: Specific optical rotation values measured for $\left[\mathrm{CD}(+)_{254}\right]-3$ in different solvents at $25{ }^{\circ} \mathrm{C}$.

Table S6: Specific optical rotation values measured for $\left[\mathrm{CD}(-)_{254}\right]-3$ in different solvents at $25{ }^{\circ} \mathrm{C}$.

Table S7: B3LYP/6-31G** frequencies (scaled by 0.968) of the ester $v C=\mathrm{O}$ stretching vibration of $M M-2$ (IEFPCM $=\mathrm{CH}_{2} \mathrm{Cl}_{2}$ and $\mathrm{C}_{2} \mathrm{D}_{2} \mathrm{Cl}_{4}$ ) for the acetate group pointing inward or outward the cavity. 
Analytical separation for compound 1

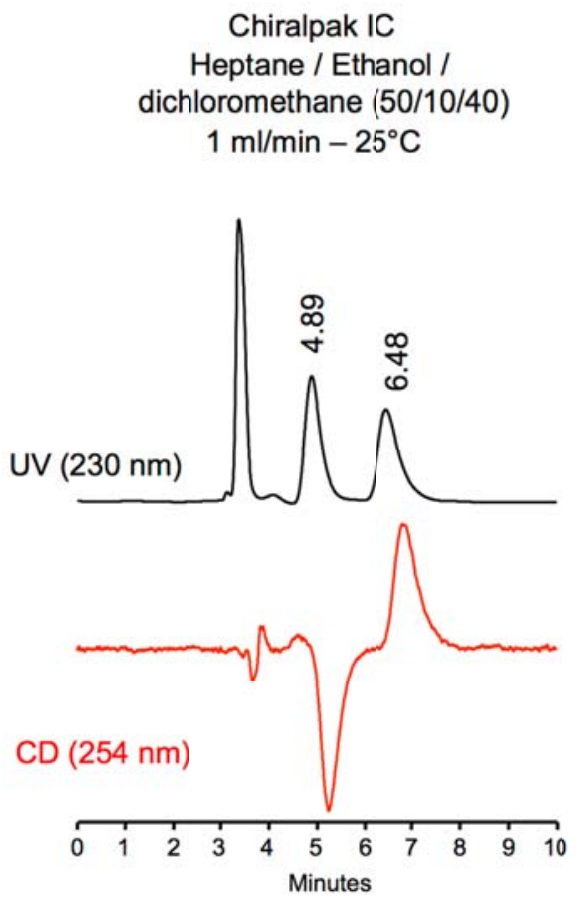

$\begin{array}{lllllllll}\text { Column } & \text { Mobile Phase } & \mathrm{t}_{1} & \mathrm{k}_{1} & \mathrm{t}_{2} & \mathrm{k}_{2} & \alpha & \mathrm{Rs}\end{array}$

Chiralpak IC heptane/EtOH/ $\mathrm{CH}_{2} \mathrm{Cl}_{2}(50 / 10 / 40) \quad 4.89(-) \quad 0.636 .48(+) 1.161 .842 .23$

Figure S1: Chromatograms (Chiralpak IC, 250 x $4.6 \mathrm{~mm}$, heptane/ethanol/ $\mathrm{CH}_{2} \mathrm{Cl}_{2}$ : 50/10/40, $1 \mathrm{~mL} / \mathrm{min}$ at $25{ }^{\circ} \mathrm{C}$ ) of the (rac)-1 before preparative separation on Chiralpak IC ( $250 \times 10$ $\mathrm{mm}$, heptane/ethanol/ $\left.\mathrm{CH}_{2} \mathrm{Cl}_{2}: 50 / 10 / 40,5 \mathrm{~mL} / \mathrm{min}\right)$.

Semi-preparative separation for compound $\mathbf{1}$

Sample preparation: About $460 \mathrm{mg}$ of compound (rac)-1 are dissolved in $18 \mathrm{~mL}$ of dichloromethane. Chromatographic conditions: Chiralpak IC $(250 \mathrm{x} 10 \mathrm{~mm})$, hexane/ethanol/dichloromethane (5/1/4) as mobile phase, flow-rate $=5 \mathrm{ml} / \mathrm{min}$, UV detection at $230 \mathrm{~nm}$. Injections (stacked): 180 times $100 \mu \mathrm{L}$, every 5 minutes.

The first eluted enantiomer is collected between 4.2 and 5.2 minutes and the second one between 6 and 7.5 minutes.

First fraction: $180 \mathrm{mg}$ of the first eluted $\left[\mathrm{CD}(-)_{254}\right]-\mathbf{1}$ with ee $>99.5 \%$ on Jasco CD-1595 circular dichroism detector at $254 \mathrm{~nm}$.

Second fraction: $200 \mathrm{mg}$ of the second eluted $\left[\mathrm{CD}(+)_{254}\right]-\mathbf{1}$ with ee $>99 \%$ on Jasco CD-1595 circular dichroism detector at $254 \mathrm{~nm}$. 


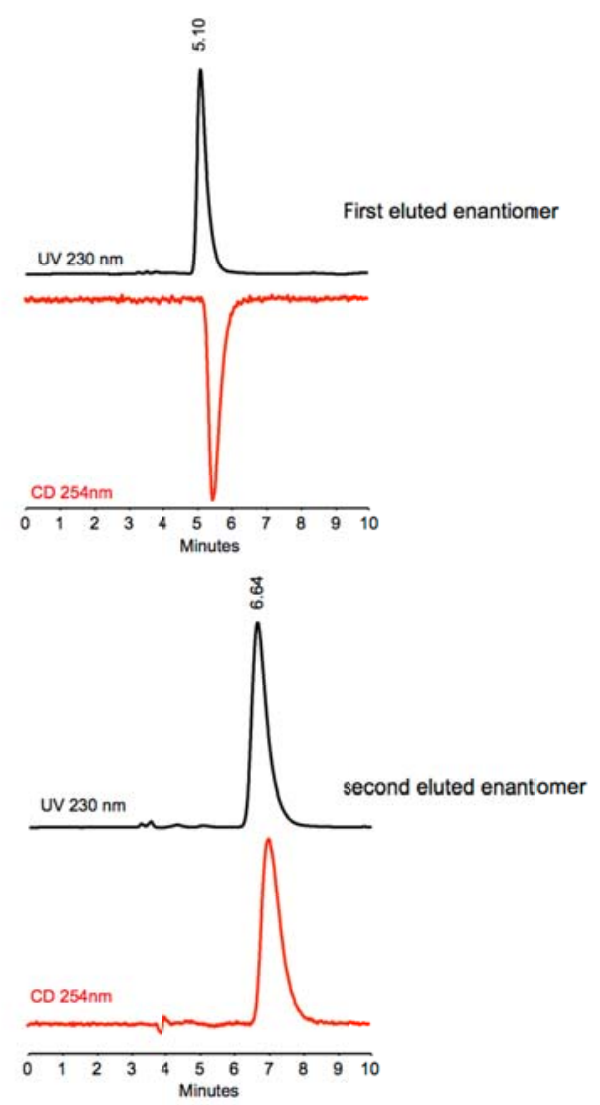

Figure S2: Chromatograms (Chiralpak IC, 250 x $4.6 \mathrm{~mm}$, heptane/ethanol/ $\mathrm{CH}_{2} \mathrm{Cl}_{2}$ : 50/10/40, $1 \mathrm{~mL} / \mathrm{min}$ at $25{ }^{\circ} \mathrm{C}$ ) of the collected $\left[\mathrm{CD}(-)_{254}\right]-\mathbf{1}$ and $\left[\mathrm{CD}(+)_{254}\right]-\mathbf{1}$ after preparative separation on Chiralpak IC (250 x $10 \mathrm{~mm}$, heptane/ethanol/ $\left.\mathrm{CH}_{2} \mathrm{Cl}_{2}: 50 / 10 / 40,5 \mathrm{~mL} / \mathrm{min}\right)$. Detection performed by UV-Vis spectroscopy at $230 \mathrm{~nm}$ (black chromatograms) and CD spectroscopy at $254 \mathrm{~nm}$ (red chromatograms).

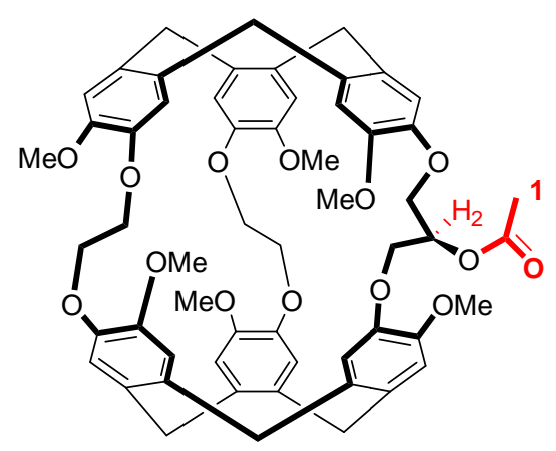


Synthesis of cryptophane 2: Acetic anhydride ( $0.7 \mathrm{~mL}, 7.4 \mathrm{mmol}, 10$ equiv.) was added dropwise at $0{ }^{\circ} \mathrm{C}$ to a solution of cryptophane-223(OMe) $)_{6} \mathrm{OH}(0.7 \mathrm{~g}, 0.75 \mathrm{mmol})$ in freshly distilled $\mathrm{CH}_{2} \mathrm{Cl}_{2}(23 \mathrm{~mL})$ and pyridine $(3.5 \mathrm{~mL})$. The reaction mixture was stirred for 48 hours at room temperature. The solution was then quenched at $0{ }^{\circ} \mathrm{C}$ with concentrated $\mathrm{NaHCO}_{3}(10$ ml) for 10 minutes and then poured in $20 \mathrm{~mL}$ of $\mathrm{H}_{2} \mathrm{O}$. The aqueous layer was extracted 5 times with $\mathrm{CH}_{2} \mathrm{Cl}_{2}$ and then dried over $\mathrm{Na}_{2} \mathrm{SO}_{4}$. After filtration the solvent was evaporated under reduced pressure. The crude product was subjected to column chromatography on silica gel $\left(\mathrm{CH}_{2} \mathrm{Cl}_{2}\right.$ /acetone: $\left.85 / 15\right)$ to give rise to compound 2 as a white product $(0.52 \mathrm{~g}, 71 \%) .{ }^{1} \mathrm{H}$ NMR (300 MHz, $\left.\mathrm{CDCl}_{3}, 25{ }^{\circ} \mathrm{C}\right) \delta$ ppm: 6.63-6.79 (12 s, $\left.12 \mathrm{H}\right), 4.58-4.62$ (m, 6H), 4.02-4.2 (m, 11H), 3.93 (m, 1 H), 3.73- 3.8 (6s, 18 H), 3.47 (m, 1H), 3.36-3.41 (m, 6 H), 2.17 (s, 3H). ${ }^{13} \mathrm{C}$ NMR: (75.5 MHz, $\left.\mathrm{CDCl}_{3}, 25{ }^{\circ} \mathrm{C}\right) \delta \mathrm{ppm}: 170.6,149.6$ (2C), 149.55, 149.4, 148.8, 148.1, 146.8, 146.7 (2 C), 146.6, 146.5 (2 C), 134.1, 134.1, 133.8, 133.8, 133.3, 132.8, 132.1, 131.9, 131.5, 131.4, 131.35, 131.3, 120.3, 120.2 (3 C), 117.2, 115.1, 114.2 (2 C), 113.9, 113.7, 113.35, 113.2, 70.8, 69.6, 69.5, 69.1, 68.9 (2 C), 66.6, 56.3, 56.3, 55.7, 55.65(2 C), 55.6, 36.5, 36.4; 36.2 (4 C), 21.2. HRMS(ESI-TOF) $\mathrm{m} / \mathrm{z}[\mathrm{M}+\mathrm{Na}]^{+}$calcd for $\mathrm{C}_{57} \mathrm{H}_{58} \mathrm{O}_{14} \mathrm{Na} 989.3724$, found 989.3719.

Figure S3: Experimental procedure for the synthesis of cryptophane 2.

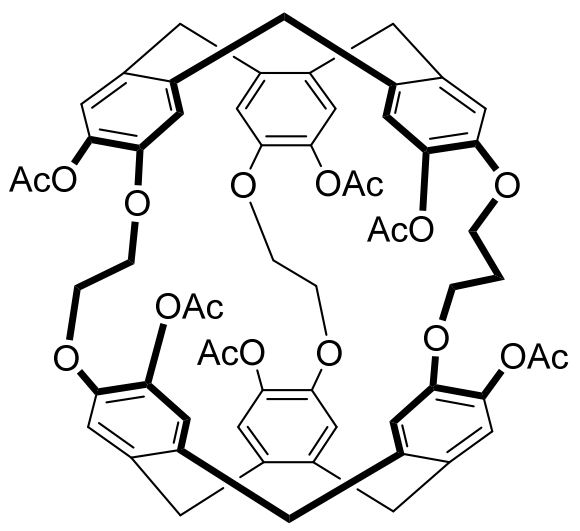


Synthesis of cryptophane 3: Acetic anhydride $(2.2 \mathrm{~mL}, 41 \mathrm{mmol})$ was added dropwise at 0 ${ }^{\circ} \mathrm{C}$ to a solution of cryptophane223(OH) $(0.35 \mathrm{~g}, 0.42 \mathrm{mmol})$ in Pyridine $(5 \mathrm{~mL})$. The reaction was stirred at room temperature for 16 hours under an argon atmosphere. Then, the reaction was quenched with a solution of sodium bicarbonate at $0{ }^{\circ} \mathrm{C}$. The solution was then extracted 5 times with $\mathrm{CH}_{2} \mathrm{Cl}_{2}$. The combined organic layers were dried over sodium sulfate. A filtration, followed by evaporation of the solvents under reduced pressure, gives rise to compound 3 as a white product. The solid was then washed on a frit with an $\mathrm{Et}_{2} \mathrm{O} / \mathrm{CH}_{2} \mathrm{Cl}_{2}$ : 75/25 mixture to give compound 3 as a clean white solid (0.31g, $71 \%$ ). ${ }^{1} \mathrm{H}$ NMR (300 MHz, $\left.\mathrm{CDCl}_{3}, 25^{\circ} \mathrm{C}\right) \delta$ ppm: 6.94 (s, $\left.2 \mathrm{H}\right), 6.91(2 \mathrm{H}), 6.89(2 \mathrm{H}), 6.87(2 \mathrm{H}), 6.86(2 \mathrm{H}), 6.62(2 \mathrm{H})$, 4.65-4.58 (m, 6 H), 4.28-4.286 (2 H, m), 4.16-4.15 (m, 2 H), 4.04 - 3.8 (m, 8 H), 3.5-3.4 (m, 6H), 2.31 (s, $6 \mathrm{H}), 2.29$ (s, $6 \mathrm{H}), 2.25$ (s, $6 \mathrm{H}), 2.09$ (m, 2 H). ${ }^{13} \mathrm{C}$ NMR (75.5 MHz, $\mathrm{CDCl}_{3}, 25$ $\left.{ }^{\circ} \mathrm{C}\right) \delta$ ppm: 168.5 (4 C), 168.3 (2 C), 149.3 (2 C), 149.25 (2 C), 149.0 (2 C), 140.5 (2 C), 140.3 (2 C), 138.7 (2 C), 138.6 (2 C), 137.8 (2 C), 136.7 (2 C), 133.6 (2 C), 133.4 (2 C), 131.2 (2 C), 124.4 (2 C), 124.0 (2 C), 123.3 (2 C), 120.9 (2 C), 120.7 (2 C), 113.6 (2 C), 69.8 (2 C), 69.1 (2 C), 63.7 (2 C), 36.4 (2 C), 36.1 (4 C), 20.7 (4 C), 20.6 (2 C). HRMS(ESI-TOF) $m / z[\mathrm{M}+\mathrm{Na}]^{+}$calcd for $\mathrm{C}_{61} \mathrm{H}_{56} \mathrm{O}_{18} \mathrm{Na} 1099.3364$, found 1099.3359.

Figure S4: Experimental procedure for the synthesis of cryptophane 3. 


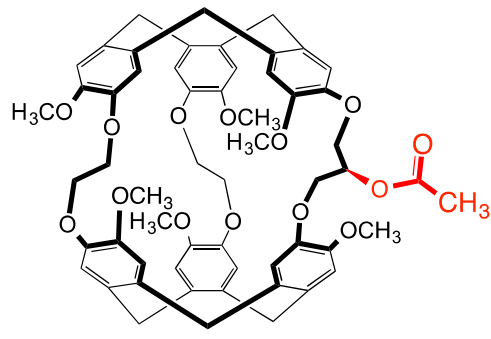

(S,S)-Whelk-O

Heptane/ethanol/ $\mathrm{CH}_{2} \mathrm{Cl}_{2}$ $(20 / 40 / 40)$

$1 \mathrm{ml} / \mathrm{min}-25^{\circ} \mathrm{C}$
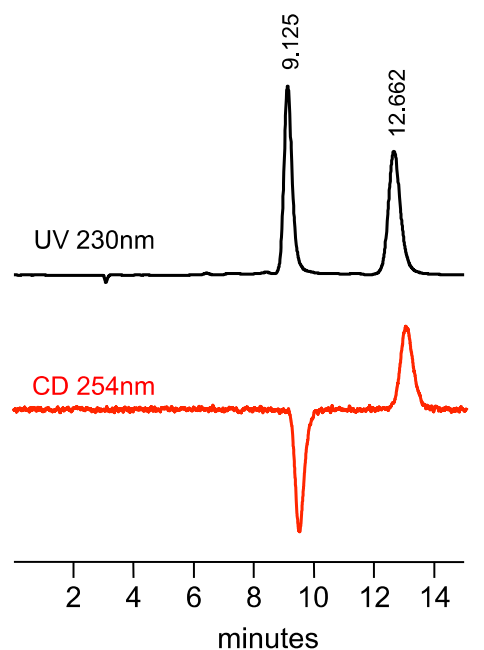

Column

$(S, S)-$ Whelk-O
Mobile Phase

heptane/EtOH/ $\mathrm{CH}_{2} \mathrm{Cl}_{2}$ 20/40/40

$\begin{array}{llllll}\mathrm{t}_{1} & \mathrm{k}_{1} & \mathrm{t}_{2} & \mathrm{k}_{2} & \alpha & \mathrm{Rs}\end{array}$

$9.13(-) \quad 2.1012 .67(+) 3.291 .57 \quad 5.72$

Figure S5: Chromatograms ((S,S)-Whelk-O ${ }_{1}, 250$ x $4.6 \mathrm{~mm}$, heptane/ethanol/ $\mathrm{CH}_{2} \mathrm{Cl}_{2}$ : 20/40/40, $1 \mathrm{~mL} / \mathrm{min}$ at $25^{\circ} \mathrm{C}$ ) of the (rac)-2 before preparative separation on (S,S)-Whelk-O (250 x $10 \mathrm{~mm}$, heptane/ethanol/ $\mathrm{CH}_{2} \mathrm{Cl}_{2}: 20 / 40 / 40,5 \mathrm{~mL} / \mathrm{min}$ ). 
Sample preparation: About $580 \mathrm{mg}$ of (rac)-2 are dissolved in $6 \mathrm{~mL}$ of dichloromethane. Chromatographic conditions: (S,S)-Whelk-O1 (250 x $10 \mathrm{~mm})$, heptane/ethanol/ dichloromethane (20/40/40) as mobile phase, flow-rate $=5 \mathrm{~mL} / \mathrm{min}$, UV detection at $230 \mathrm{~nm}$. Injections (stacked): 20 times $300 \mu \mathrm{L}$, every 13.8 minutes.

First fraction: $255 \mathrm{mg}$ of the first eluted $\left[\mathrm{CD}(-)_{254}\right]-2$ with ee $>99.5 \%$ on Jasco CD-1595 circular dichroism detector at $254 \mathrm{~nm}$.

Second fraction: $240 \mathrm{mg}$ of the second eluted $\left[\mathrm{CD}(+)_{254}\right]-2$ with ee $>99.5 \%$ on Jasco CD1595 circular dichroism detector at $254 \mathrm{~nm}$.

$(\mathrm{S}, \mathrm{S})-\mathrm{Whelk}_{1} \mathrm{O}_{1}$

Heptane/ethanol/ $\mathrm{CH}_{2} \mathrm{Cl}_{2}$ $(20 / 40 / 40)$

$1 \mathrm{ml} / \mathrm{min}-25^{\circ} \mathrm{C}$
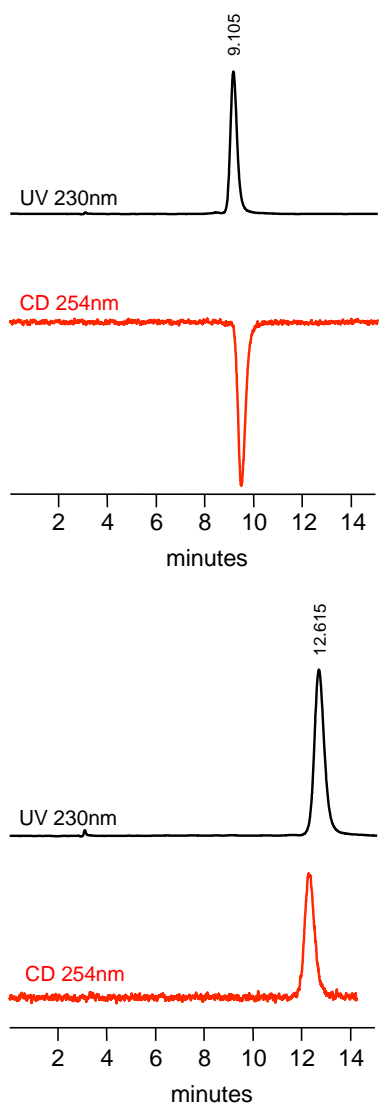

Figure S6: Chromatograms $\left((S, S)-\right.$ Whelk- $\mathrm{O}_{1}, 250$ x $4.6 \mathrm{~mm}$, heptane/ethanol/ $\mathrm{CH}_{2} \mathrm{Cl}_{2}$ : 20/40/40, $1 \mathrm{~mL} / \mathrm{min}$ at $25^{\circ} \mathrm{C}$ ) of the collected [CD(- $\left.)_{254}\right]-2$ and $\left[\mathrm{CD}(+)_{254}\right]-2$ after preparative separation on $(S, S)-W h e l k-\mathrm{O}_{1}\left(250 \times 10 \mathrm{~mm}\right.$, heptane/ethanol/ $\mathrm{CH}_{2} \mathrm{Cl}_{2}:$ 20/40/40, $\left.5 \mathrm{~mL} / \mathrm{min}\right)$. Detection performed by UV-Vis spectroscopy at $230 \mathrm{~nm}$ (black chromatograms) and CD spectroscopy at $254 \mathrm{~nm}$ (red chromatograms). 
Analytical separation for compound 3

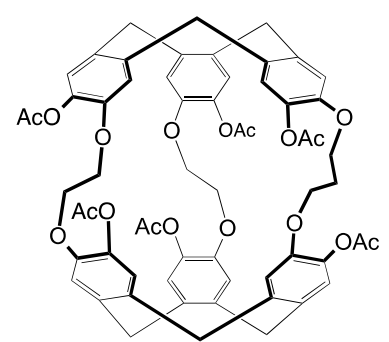

(S,S)-Whelk-O1

Ethanol/ $\mathrm{CH}_{2} \mathrm{Cl}_{2}$

$(50 / 50)$

$1 \mathrm{ml} / \mathrm{min}-25^{\circ} \mathrm{C}$
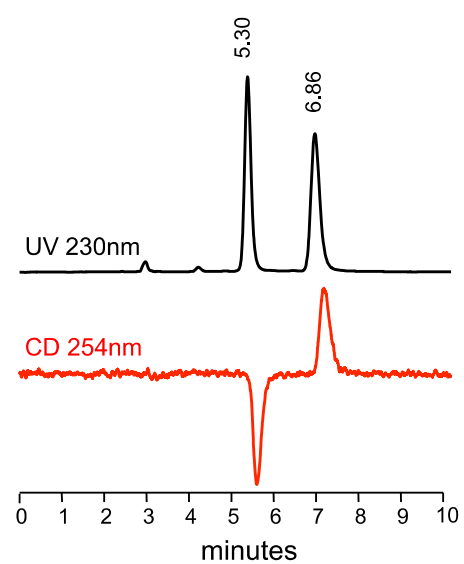

Column

Mobile Phase

$\begin{array}{llllll}\mathrm{t}_{1} & \mathrm{k}_{1} & \mathrm{t}_{2} & \mathrm{k}_{2} & \alpha & \mathrm{Rs}\end{array}$

(S,S)-Whelk-O1

ethanol/ $\mathrm{CH}_{2} \mathrm{Cl}_{2} 50 / 50$

$5.30(-) \quad 0.80 \quad 6.86(+) 1.32 \quad 1.67 \quad 4.81$

Figure S7: Chromatograms ((S,S)-Whelk- $\mathrm{O}_{1}, 250$ x $4.6 \mathrm{~mm}$, ethanol/ $\mathrm{CH}_{2} \mathrm{Cl}_{2}$ : 50/50, 1 $\mathrm{mL} / \mathrm{min}$ at $\left.25^{\circ} \mathrm{C}\right)$ of the (rac)-3 before preparative separation on $(S, S)$-Whelk-O ${ }_{1}(250 \times 10$ $\mathrm{mm}$, heptane/ethanol/ $\mathrm{CH}_{2} \mathrm{Cl}_{2}: 35 / 65,5 \mathrm{~mL} / \mathrm{min}$ ). 
Sample preparation: About $575 \mathrm{mg}$ of compound (rac)-3 are dissolved in $170 \mathrm{~mL}$ of a mixture of ethanol/dichloromethane (30/70). Chromatographic conditions: $(S, S)-W h e l k-\mathrm{O}_{1}$ (250 x $10 \mathrm{~mm})$, ethanol/dichloromethane (35/65) as mobile phase, flow-rate $=5 \mathrm{ml} / \mathrm{min}$, UV detection at $230 \mathrm{~nm}$. Injections (stacked): 340 times $500 \mu \mathrm{L}$, every 4.4 minutes.

First fraction: $235 \mathrm{mg}$ of the first eluted $\left[\mathrm{CD}(-)_{254}\right]-3$ with ee $>99 \%$ on Jasco CD-1595 circular dichroism detector at $254 \mathrm{~nm}$.

Second fraction: $200 \mathrm{mg}$ of the second eluted $\left[\mathrm{CD}(+)_{254}\right]-3$ with ee $>99.5 \%$ on Jasco CD1595 circular dichroism detector at $254 \mathrm{~nm}$.

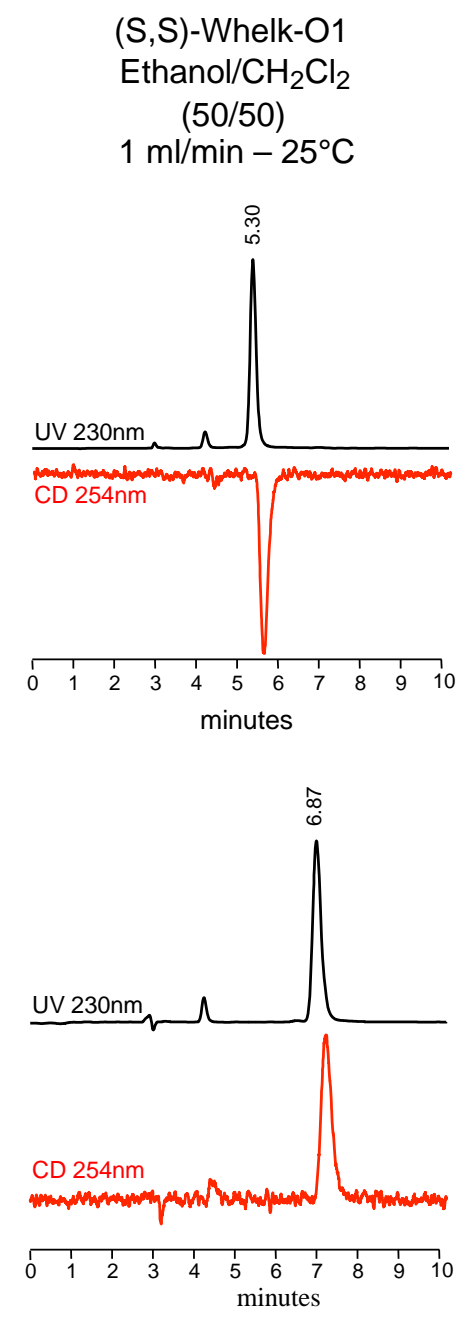

Figure S8: Chromatograms ((S,S)-Whelk- $\mathrm{O}_{1}, 250$ x $4.6 \mathrm{~mm}$, ethanol/ $\mathrm{CH}_{2} \mathrm{Cl}_{2}$ : 50/50, 1 $\mathrm{mL} / \mathrm{min}$ at $25{ }^{\circ} \mathrm{C}$ ) of the collected $\left[\mathrm{CD}(-)_{254}\right]-3$ and $\left[\mathrm{CD}(+)_{254}\right]-3$ after preparative separation on $(S, S)-$ Whelk-O ${ }_{1}\left(250 \times 10 \mathrm{~mm}\right.$, ethanol/ $\left.\mathrm{CH}_{2} \mathrm{Cl}_{2}: 50 / 50,5 \mathrm{~mL} / \mathrm{min}\right)$. Detection performed by UV-Vis spectroscopy at $230 \mathrm{~nm}$ (black chromatograms) and CD spectroscopy at $254 \mathrm{~nm}$ (red chromatograms). 


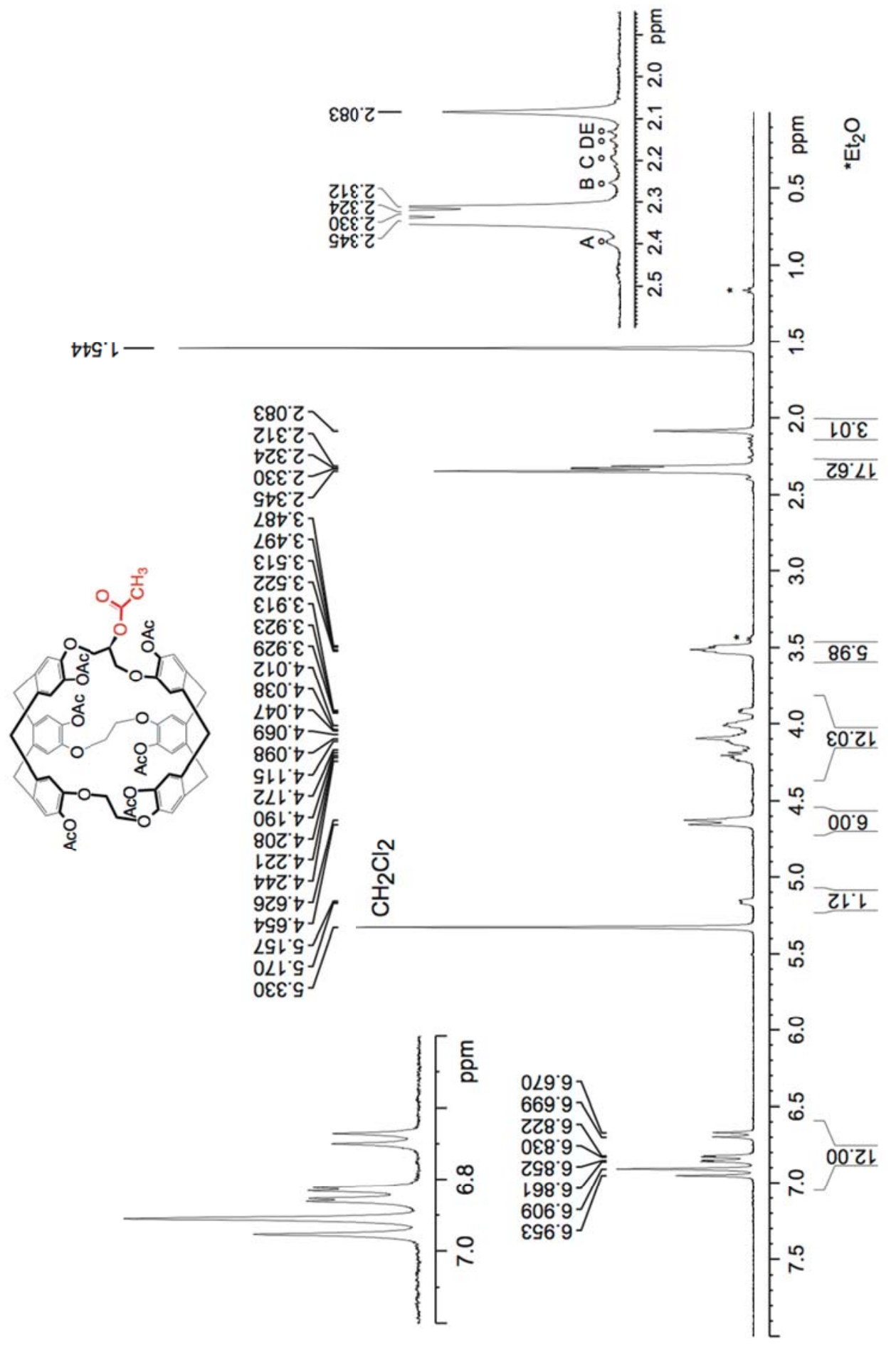

Figure S9: ${ }^{1} \mathrm{H}$ NMR spectrum (300 MHz) of (rac)-1 recorded in $\mathrm{CD}_{2} \mathrm{Cl}_{2}$ at $25{ }^{\circ} \mathrm{C}$. The letters A,B,C,D,E show protons signals related to the imploded form. 


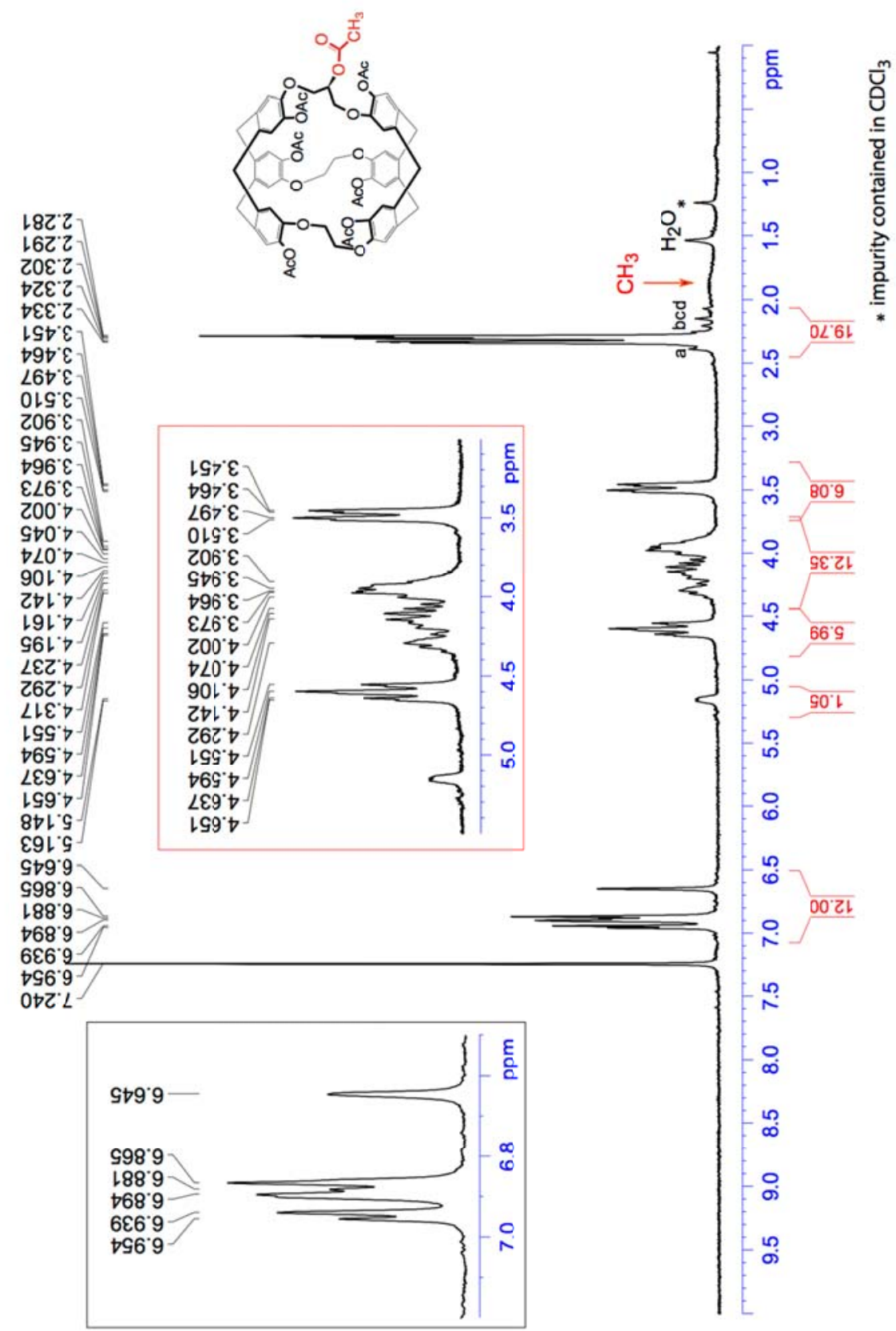

Figure S10: ${ }^{1} \mathrm{H}$ NMR spectrum (300 MHz) of (rac)-1 recorded in $\mathrm{CDCl}_{3}$ at $25{ }^{\circ} \mathrm{C}$. The letters A,B,C,D show protons signals related to the imploded form. 


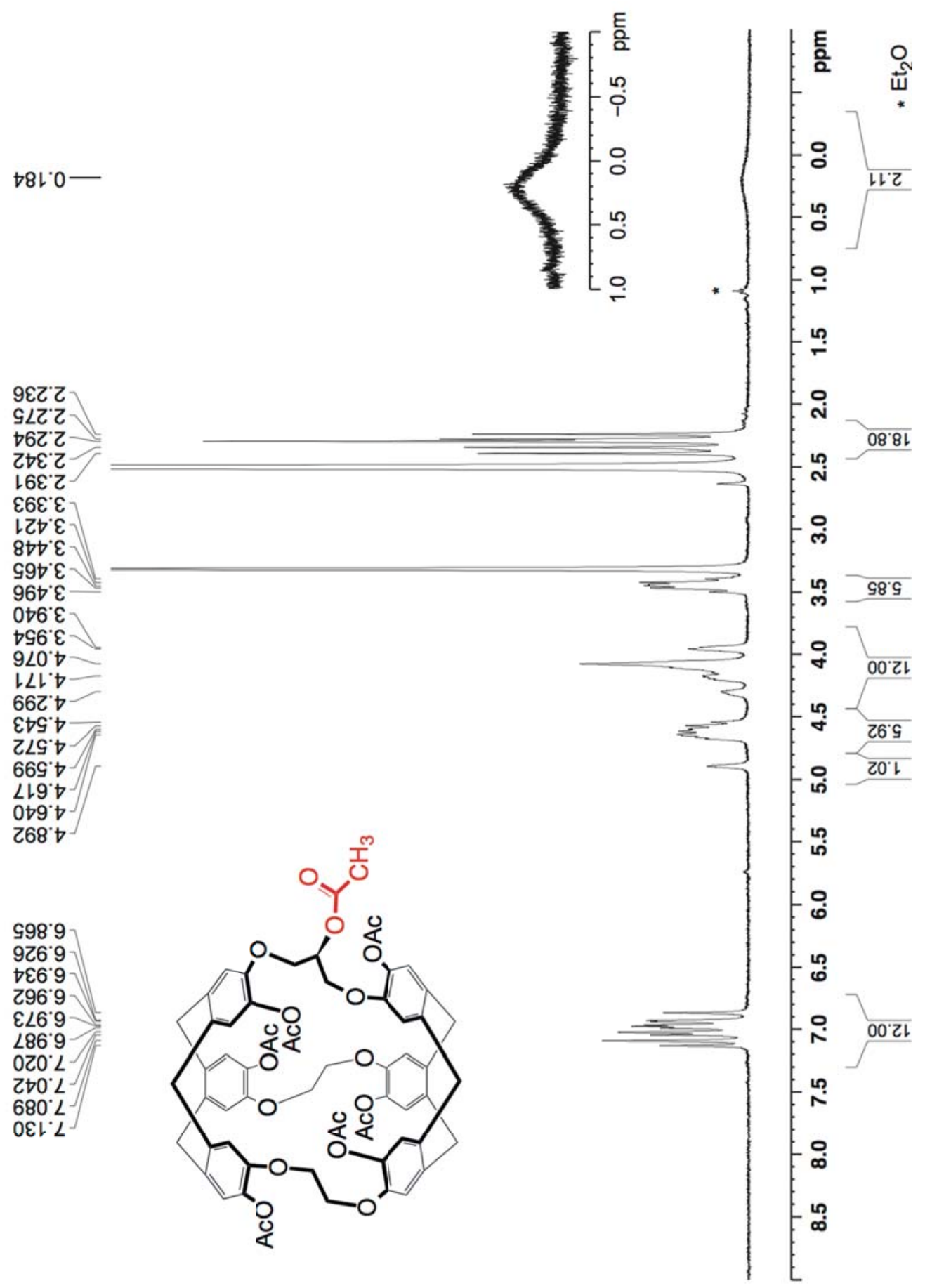

Figure S11: ${ }^{1} \mathrm{H}$ NMR spectrum (300 MHz) of (rac)-1 recorded in DMSO- $d_{6}$ at $25{ }^{\circ} \mathrm{C}$. 


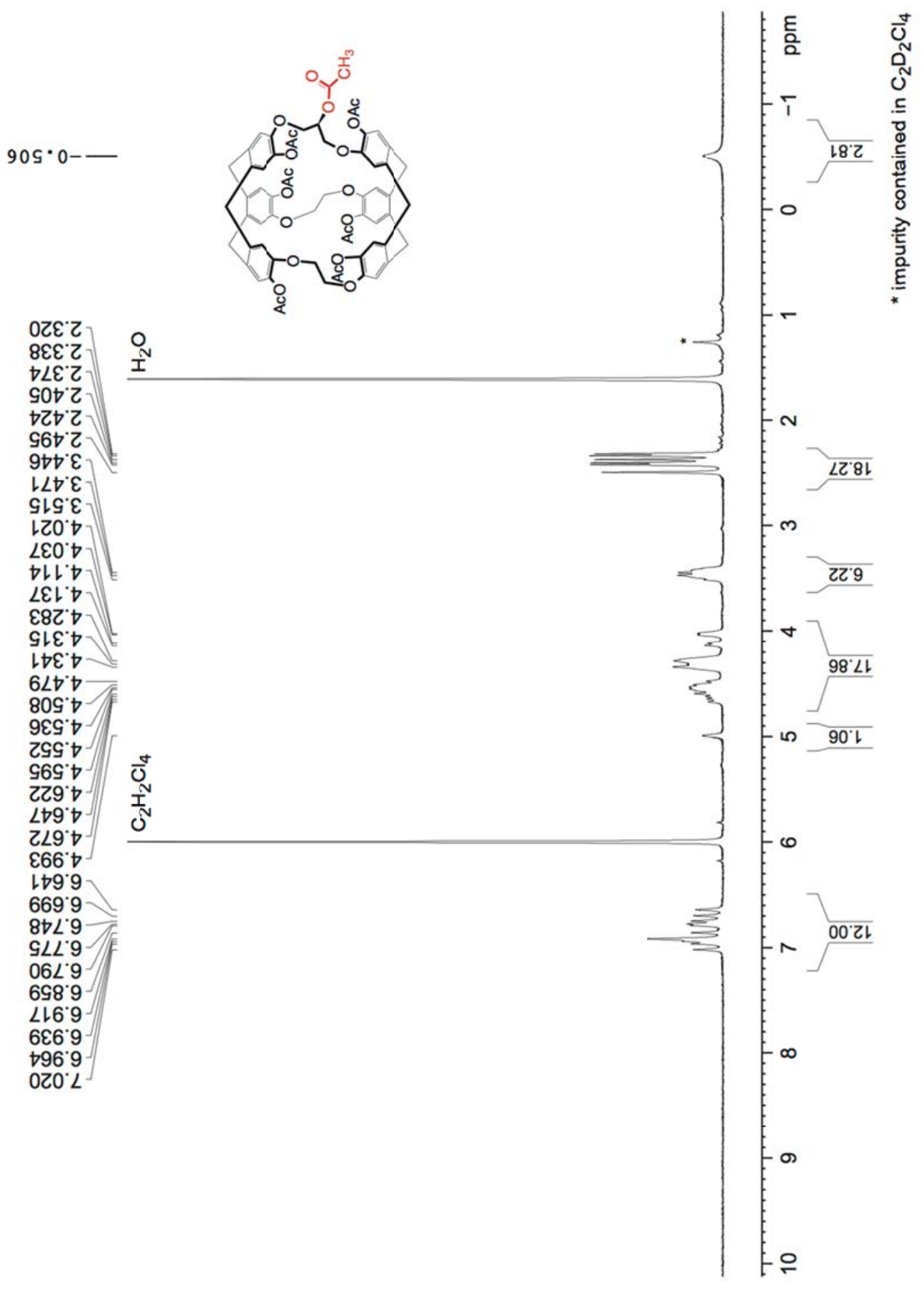

Figure S12: ${ }^{1} \mathrm{H}$ NMR spectrum (300 MHz) of (rac)-1 recorded in 1,1,2,2-tetrachloroethane- $d_{2}$ at $25{ }^{\circ} \mathrm{C}$. 


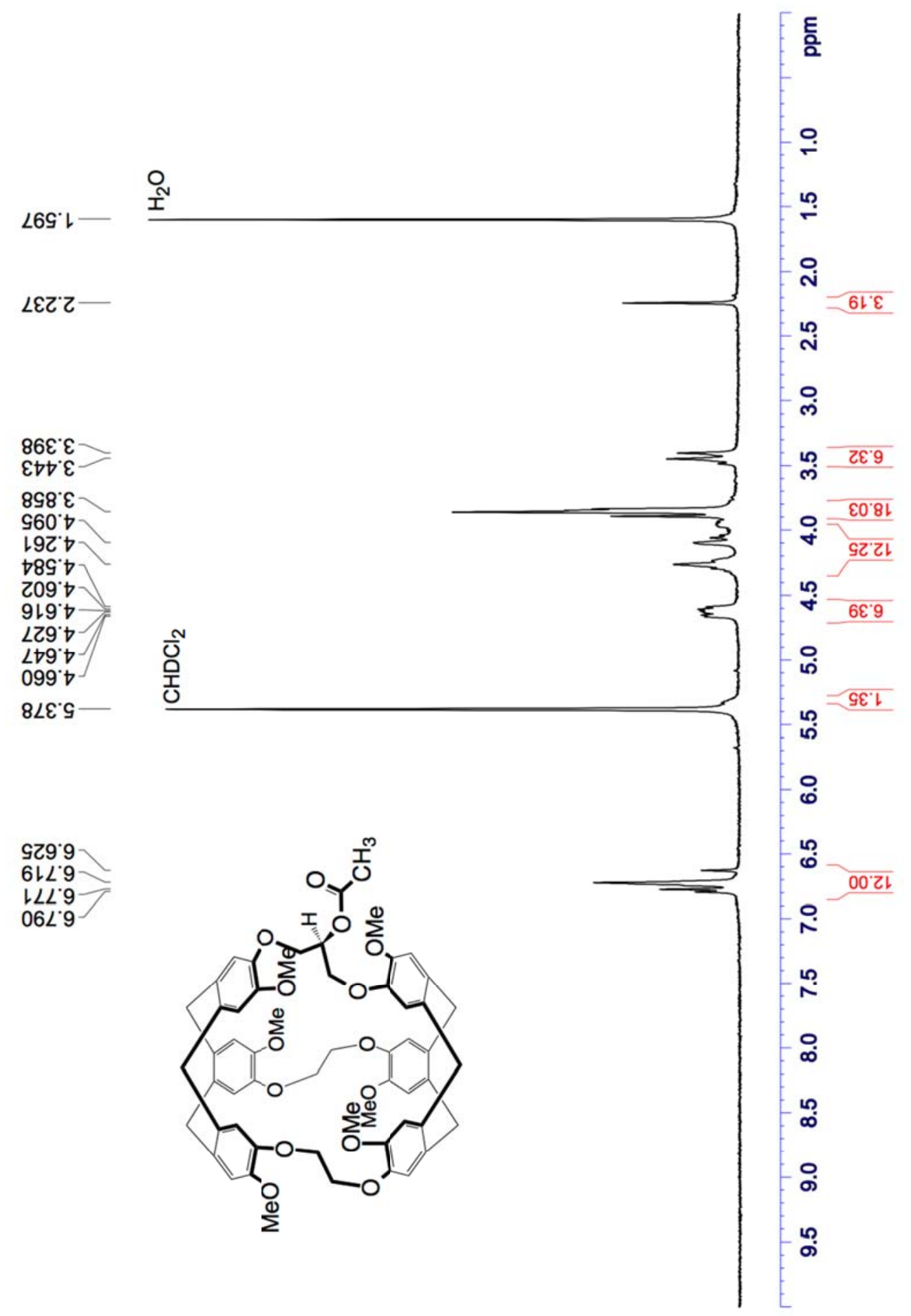

Figure S13: ${ }^{1} \mathrm{H}$ NMR spectrum (300 MHz) of (rac)-2 recorded in $\mathrm{CD}_{2} \mathrm{Cl}_{2}$ at $25{ }^{\circ} \mathrm{C}$. 


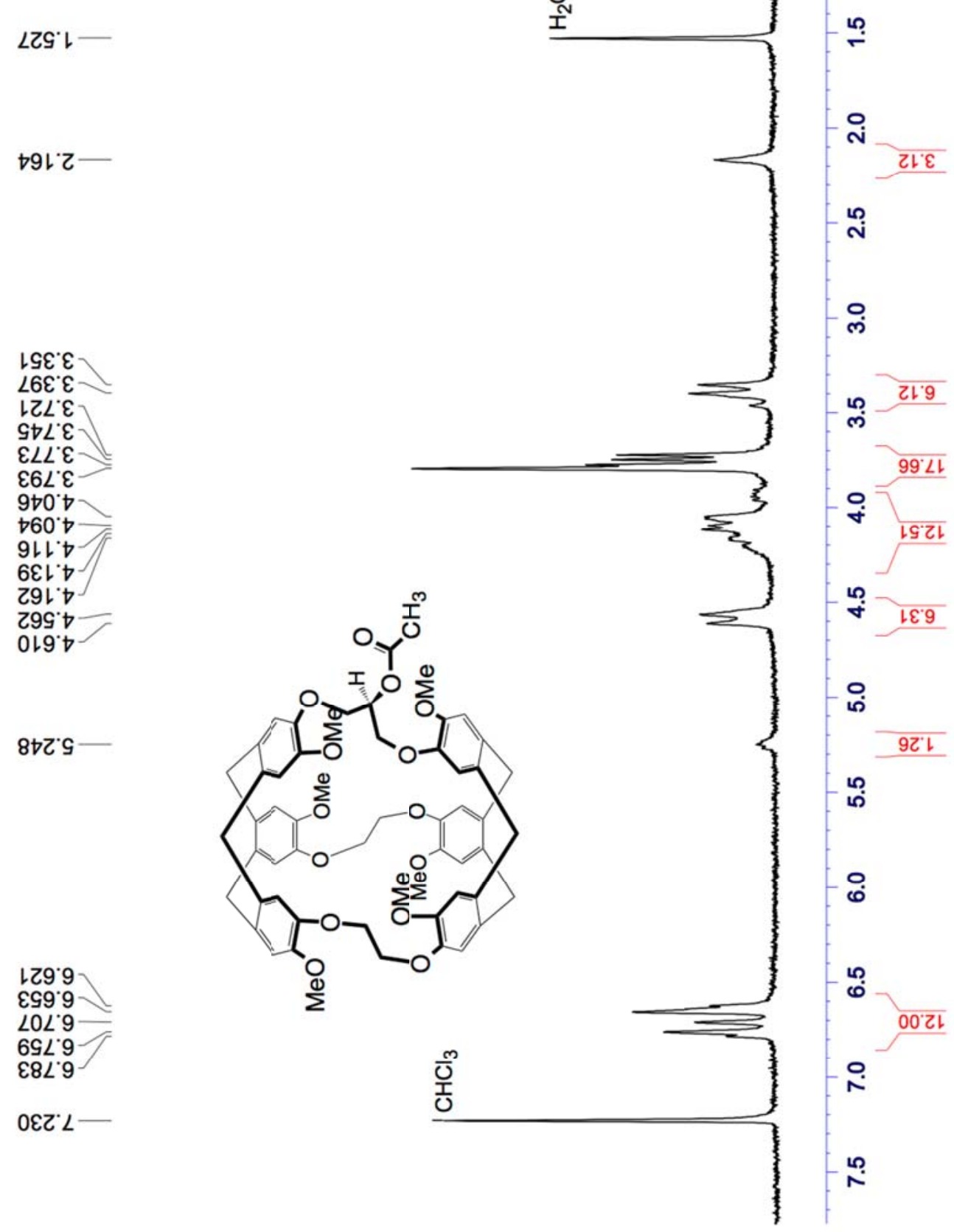

Figure S14: ${ }^{1} \mathrm{H}$ NMR spectrum (300 MHz) of (rac)-2 recorded in $\mathrm{CDCl}_{3}$ at $25{ }^{\circ} \mathrm{C}$. 


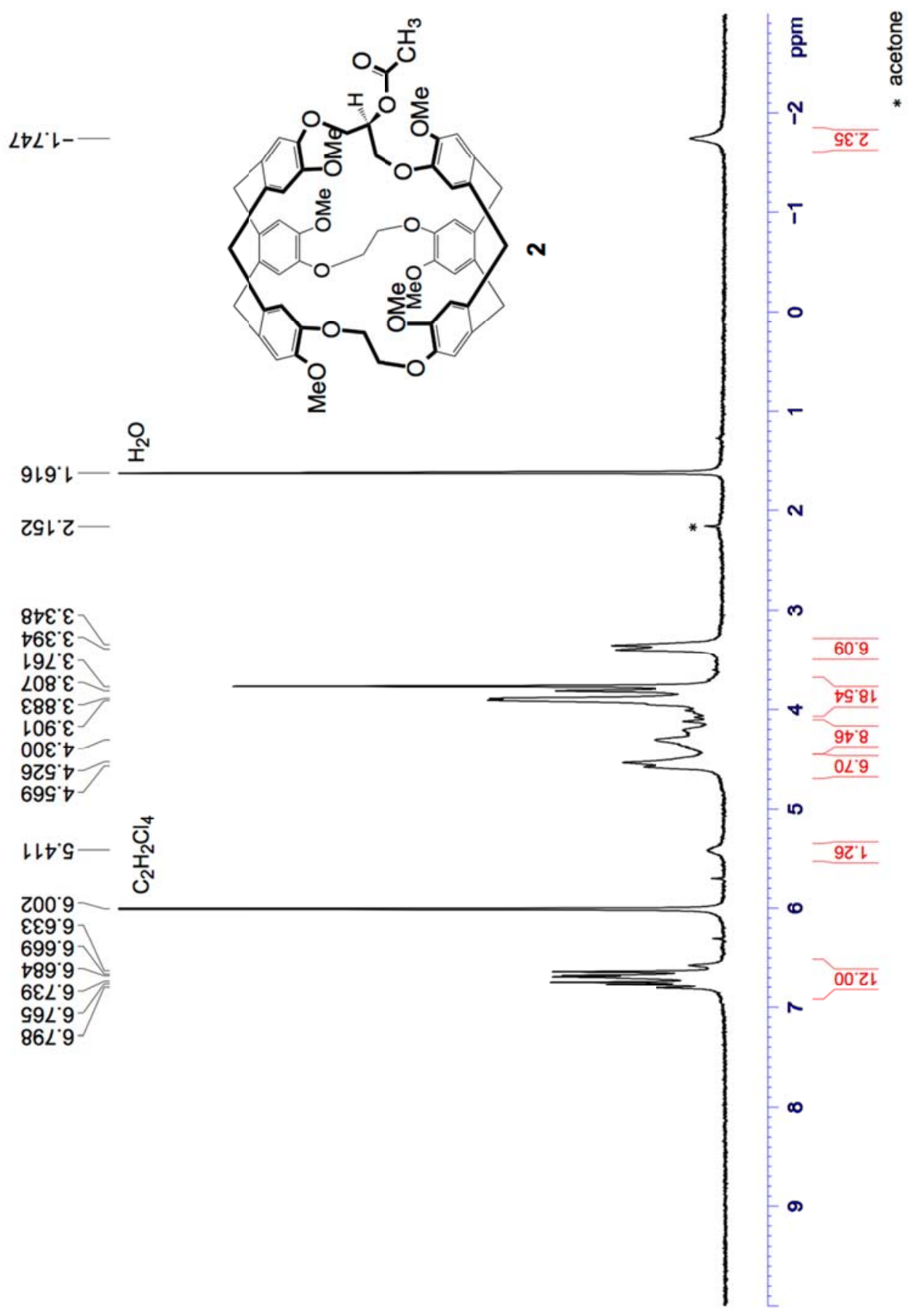

Figure S15: ${ }^{1} \mathrm{H}$ NMR spectrum (300 MHz) of (rac)-2 recorded in 1,1,2,2-tetrachloroethane- $d_{2}$ at $25^{\circ} \mathrm{C}$. 


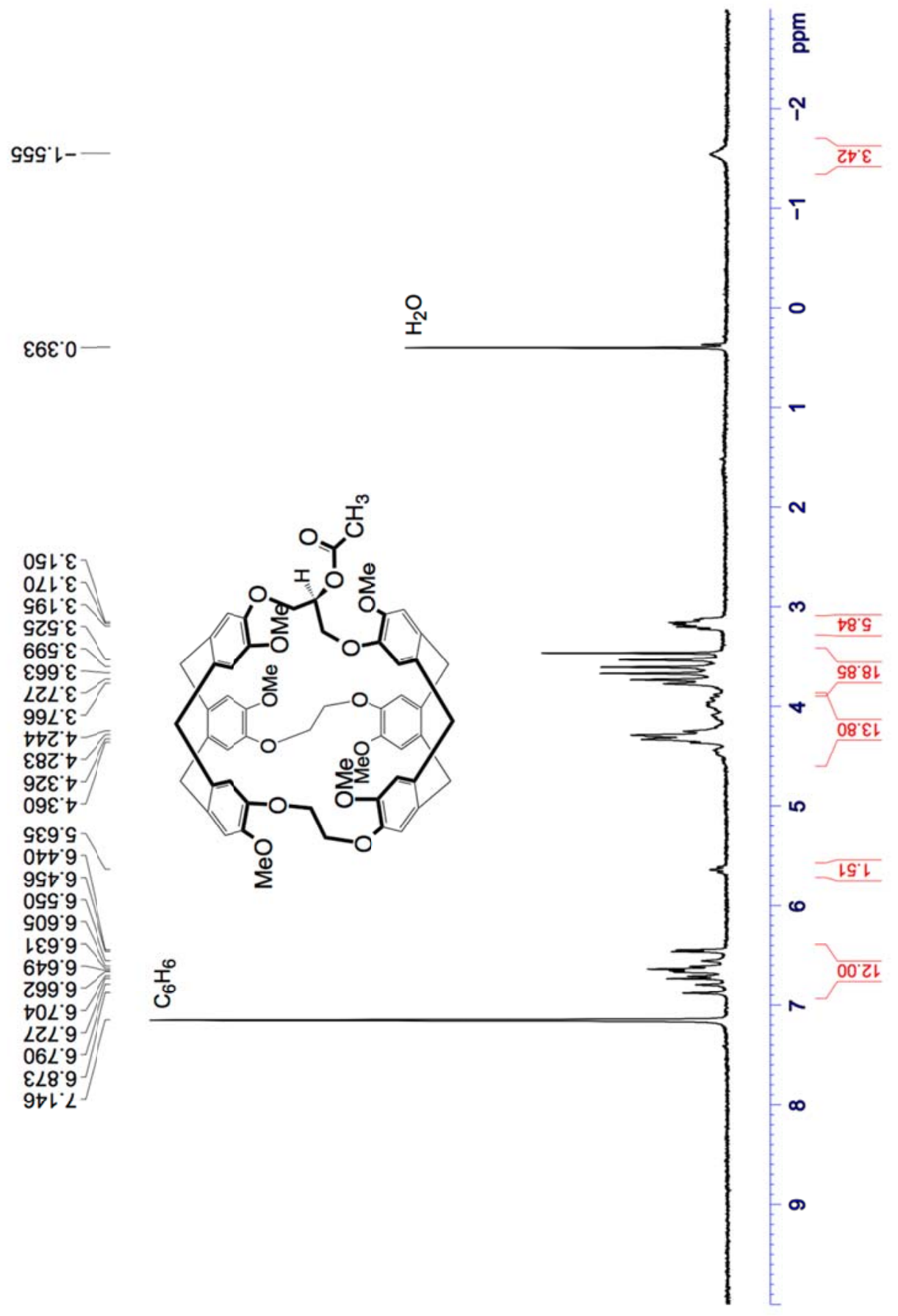

Figure S16: ${ }^{1} \mathrm{H}$ NMR spectrum (300 MHz) of (rac)-2 recorded in benzene- $\boldsymbol{d}_{6}$ at $25{ }^{\circ} \mathrm{C}$. 


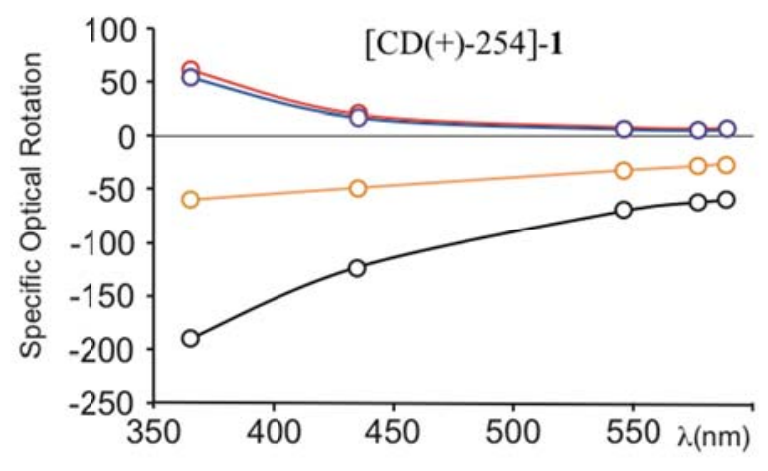

Figure S17: Specific Optical Rotation (SOR) values measured for $\left[\mathrm{CD}(+)_{254}\right]-\mathbf{1}$ and [CD(-) 254 -1 in $\mathrm{CH}_{2} \mathrm{Cl}_{2}$ (black), $\mathrm{CHCl}_{3}$ (orange), DMSO (blue) and $\mathrm{C}_{2} \mathrm{H}_{2} \mathrm{Cl}_{4}$ (red) at $25{ }^{\circ} \mathrm{C}$. Plot of the SOR $\left(10^{-1} \operatorname{deg~} \mathrm{cm}^{2} \mathrm{~g}^{-1}\right)$ values versus $\lambda(\mathrm{nm})$ for the $\left[\mathrm{CD}(+)_{254}\right]-\mathbf{1}$ enantiomer.

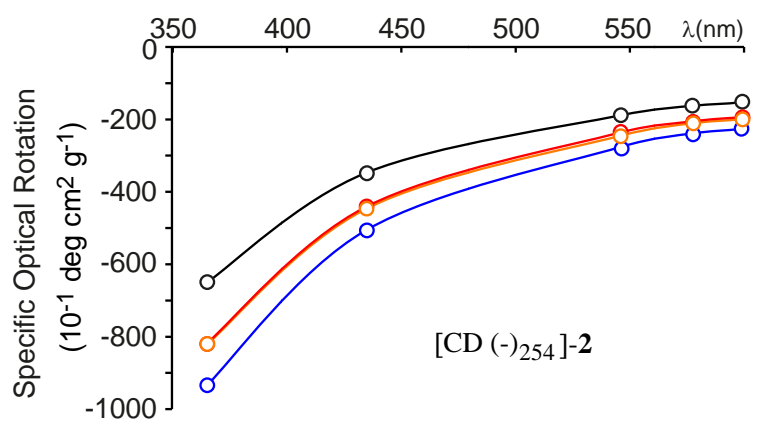

Figure S18: Specific Optical Rotation (SOR) values measured for $\left[\mathrm{CD}(+)_{254}\right]-2$ and [CD(-) 254 ]-2 in $\mathrm{CH}_{2} \mathrm{Cl}_{2}$ (black), $\mathrm{CHCl}_{3}$ (orange), DMSO (blue) and $\mathrm{C}_{2} \mathrm{H}_{2} \mathrm{Cl}_{4}$ (red) at $25{ }^{\circ} \mathrm{C}$. Plot of the SOR $\left(10^{-1} \operatorname{deg~} \mathrm{cm}^{2} \mathrm{~g}^{-1}\right)$ values versus $\lambda(\mathrm{nm})$ for the $\left[\mathrm{CD}(+)_{254}\right]-2$ enantiomer.

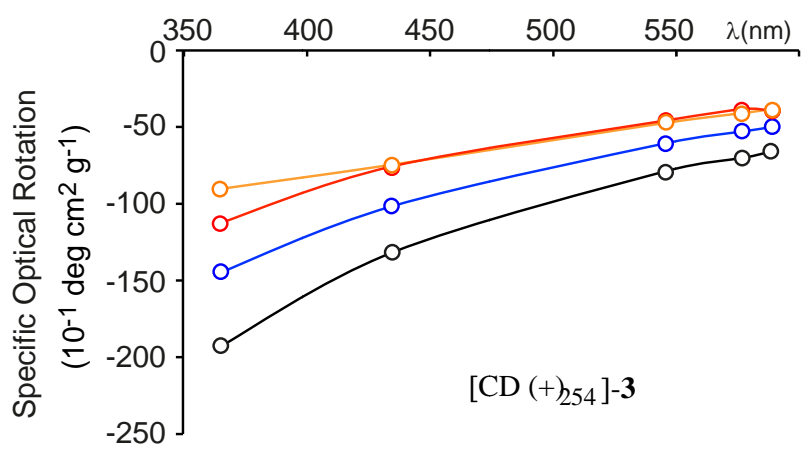

Figure S19: Specific Optical Rotation (SOR) values measured for $\left[\mathrm{CD}(+)_{254}\right]-3$ and [CD(-) 254$]-3$ in $\mathrm{CH}_{2} \mathrm{Cl}_{2}$ (black), $\mathrm{CHCl}_{3}$ (orange), DMSO (blue) and $\mathrm{C}_{2} \mathrm{H}_{2} \mathrm{Cl}_{4}$ (red) at $25{ }^{\circ} \mathrm{C}$. Plot of the SOR $\left(10^{-1} \operatorname{deg~} \mathrm{cm}^{2} \mathrm{~g}^{-1}\right)$ values versus $\lambda(\mathrm{nm})$ for the $\left[\mathrm{CD}(+)_{254}\right]-3$ enantiomer. 

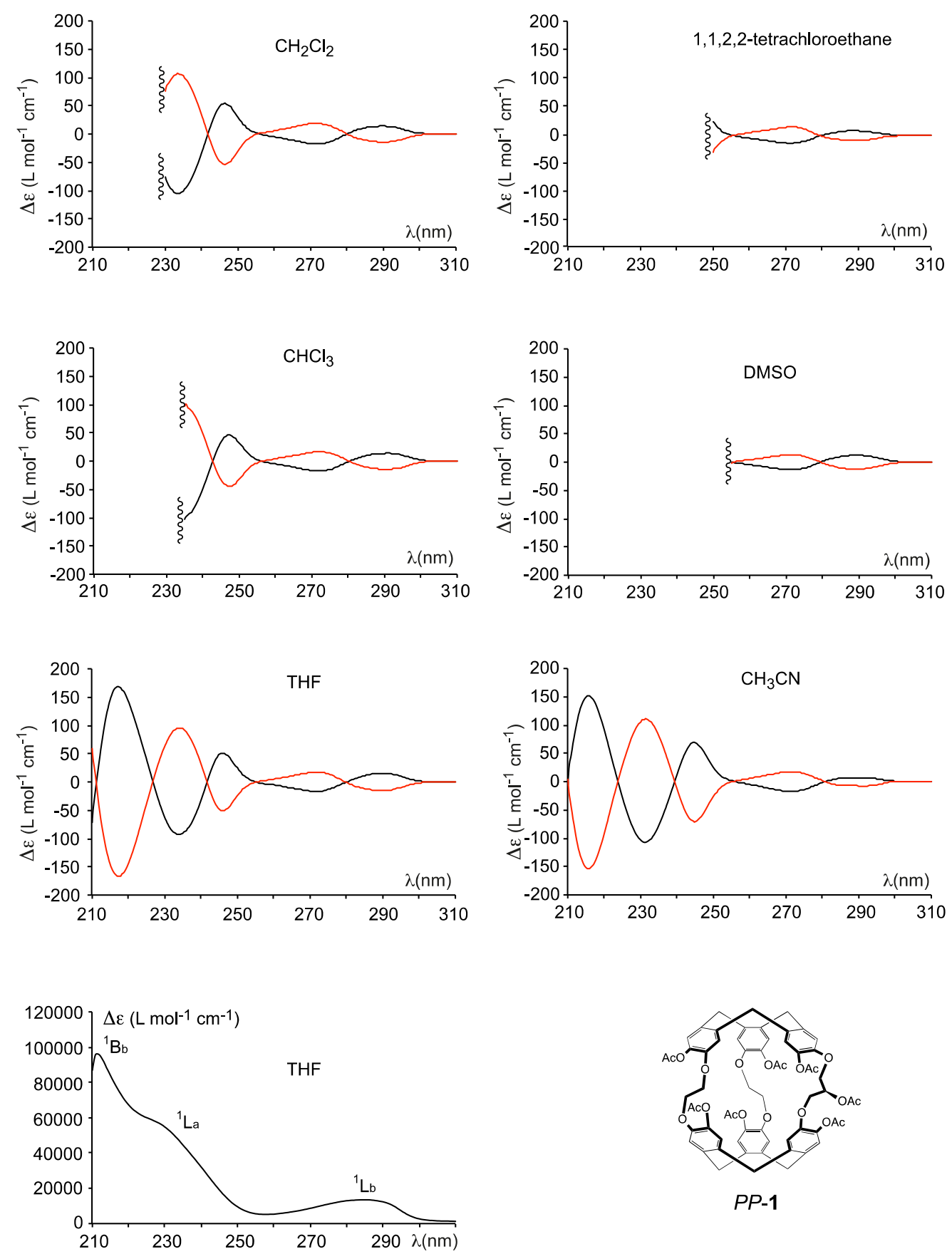

Figure S20: ECD spectra of $\left[\mathrm{CD}(+)_{254}\right]-\mathbf{1}$ (black spectra) and $\left[\mathrm{CD}(-)_{254}\right]-\mathbf{1}$ (red spectra) recorded in $\mathrm{CH}_{2} \mathrm{Cl}_{2}, \mathrm{CHCl}_{3}$, THF, $\mathrm{CH}_{3} \mathrm{CN}$, DMSO and $\mathrm{C}_{2} \mathrm{H}_{2} \mathrm{Cl}_{4}$ at $20^{\circ} \mathrm{C}$. $\left(\mathrm{c}=10^{-4}-10^{-5} \mathrm{M}\right)$. UV-visible spectrum of 1 recorded in THF at $25^{\circ} \mathrm{C}\left(\mathrm{c}=1.1210^{-5} \mathrm{M}\right)$. 

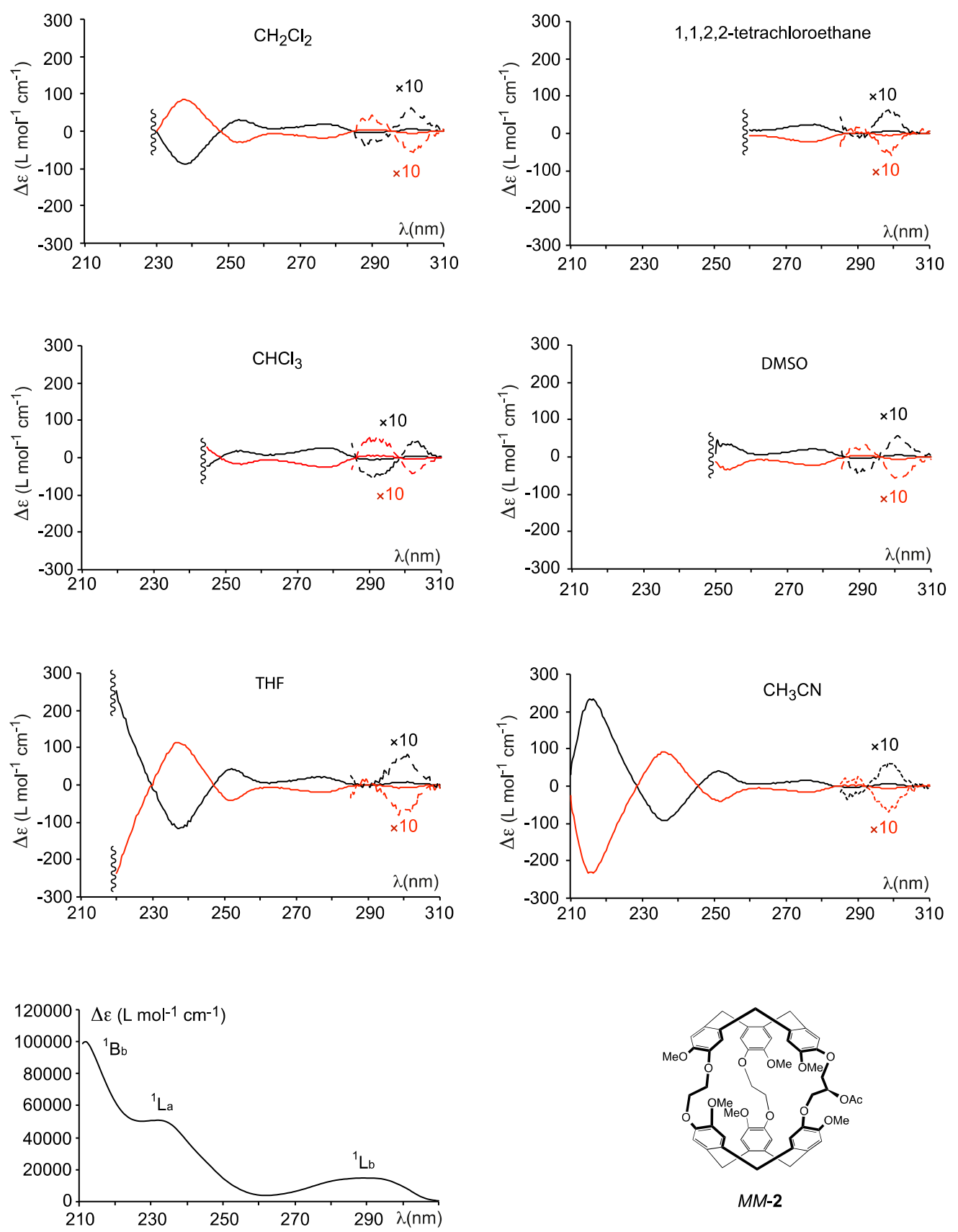

Figure S21: ECD spectra of $\left[\mathrm{CD}(+)_{254}\right]-2$ (black spectra) and $\left[\mathrm{CD}(-)_{254}\right]-2$ (red spectra) recorded in $\mathrm{CH}_{2} \mathrm{Cl}_{2}, \mathrm{CHCl}_{3}$, THF, $\mathrm{CH}_{3} \mathrm{CN}$, DMSO and $\mathrm{C}_{2} \mathrm{H}_{2} \mathrm{Cl}_{4}$ at $20^{\circ} \mathrm{C}$. $\left(\mathrm{c}=10^{-4}-10^{-5} \mathrm{M}\right)$. $\mathrm{UV}$-visible spectrum of 2 recorded in THF at $25^{\circ} \mathrm{C}\left(\mathrm{c}=1.0210^{-5} \mathrm{M}\right)$. 

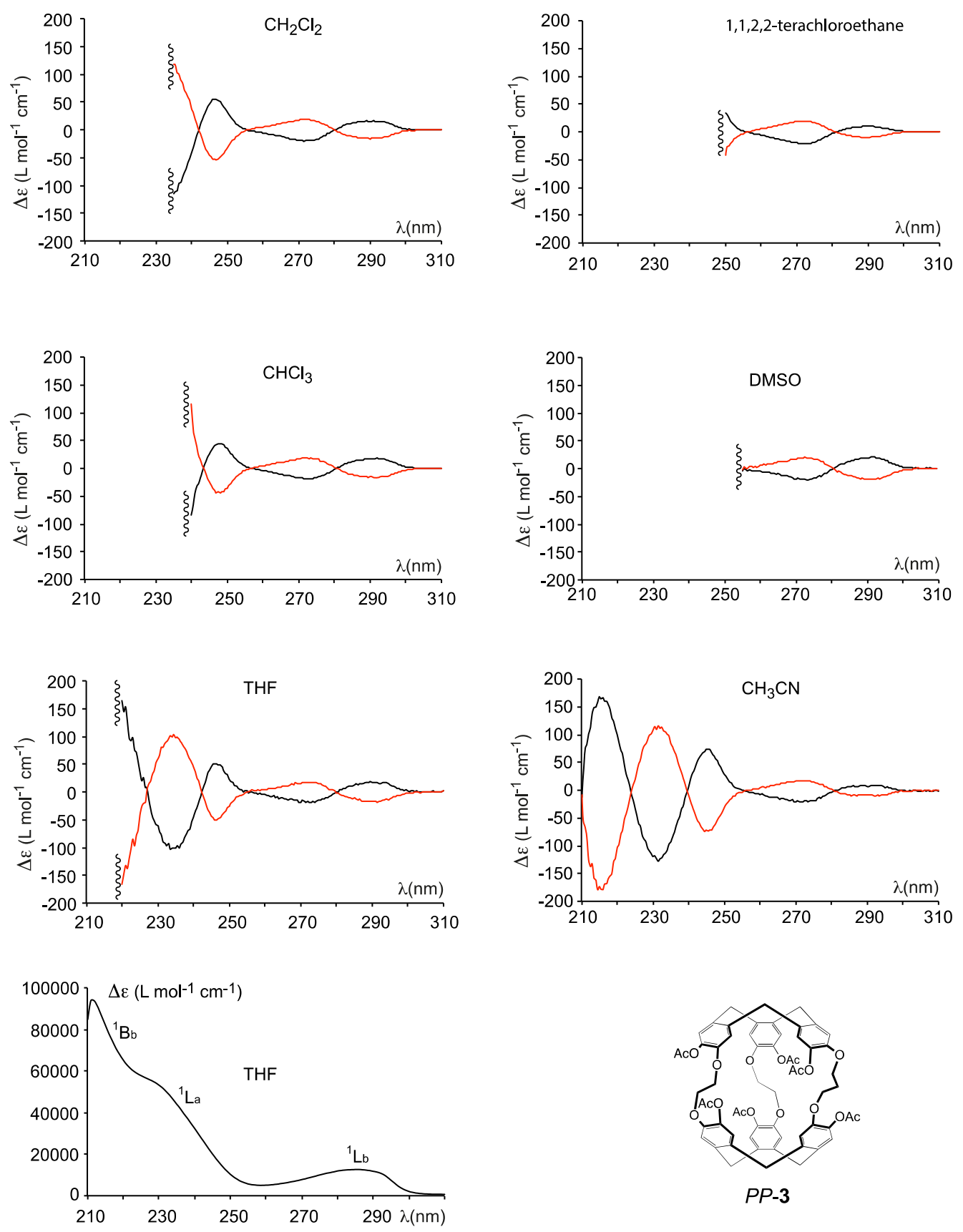

Figure S22: ECD spectra of $\left[\mathrm{CD}(+)_{254}\right]-3$ (black spectra) and [CD(-) $\left.)_{254}\right]-3$ (red spectra) recorded in $\mathrm{CH}_{2} \mathrm{Cl}_{2}, \mathrm{CHCl}_{3}$, THF, $\mathrm{CH}_{3} \mathrm{CN}$, DMSO and $\mathrm{C}_{2} \mathrm{H}_{2} \mathrm{Cl}_{4}$ at $20^{\circ} \mathrm{C}$. $\left(\mathrm{c}=10^{-4}-10^{-5} \mathrm{M}\right)$. $\mathrm{UV}$-visible spectrum of 3 recorded in THF at $25^{\circ} \mathrm{C}\left(\mathrm{c}=0.9910^{-5} \mathrm{M}\right)$. 

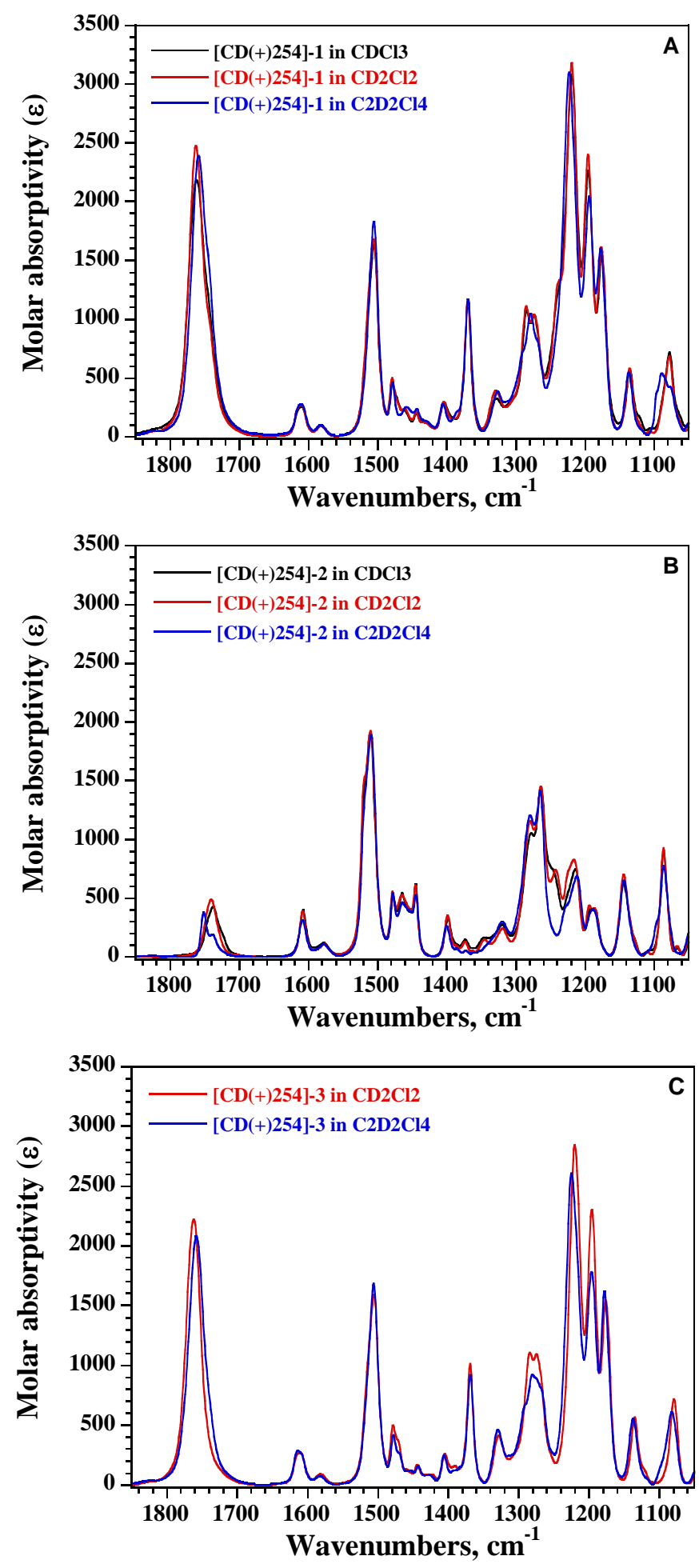

Figure S23: IR spectra of a) $\left[\mathrm{CD}(+)_{254}\right]-1$, b) $\left[\mathrm{CD}(+)_{254}\right]-2$ and $\left[\mathrm{CD}(+)_{254}\right]-3$ c) in $\mathrm{CDCl}_{3}$ (black spectra), $\mathrm{CD}_{2} \mathrm{Cl}_{2}$ (red spectra) and $\mathrm{C}_{2} \mathrm{D}_{2} \mathrm{Cl}_{4}$ (blue spectra) solvents (0.015 mM, $250 \mu \mathrm{m}$ path length). 

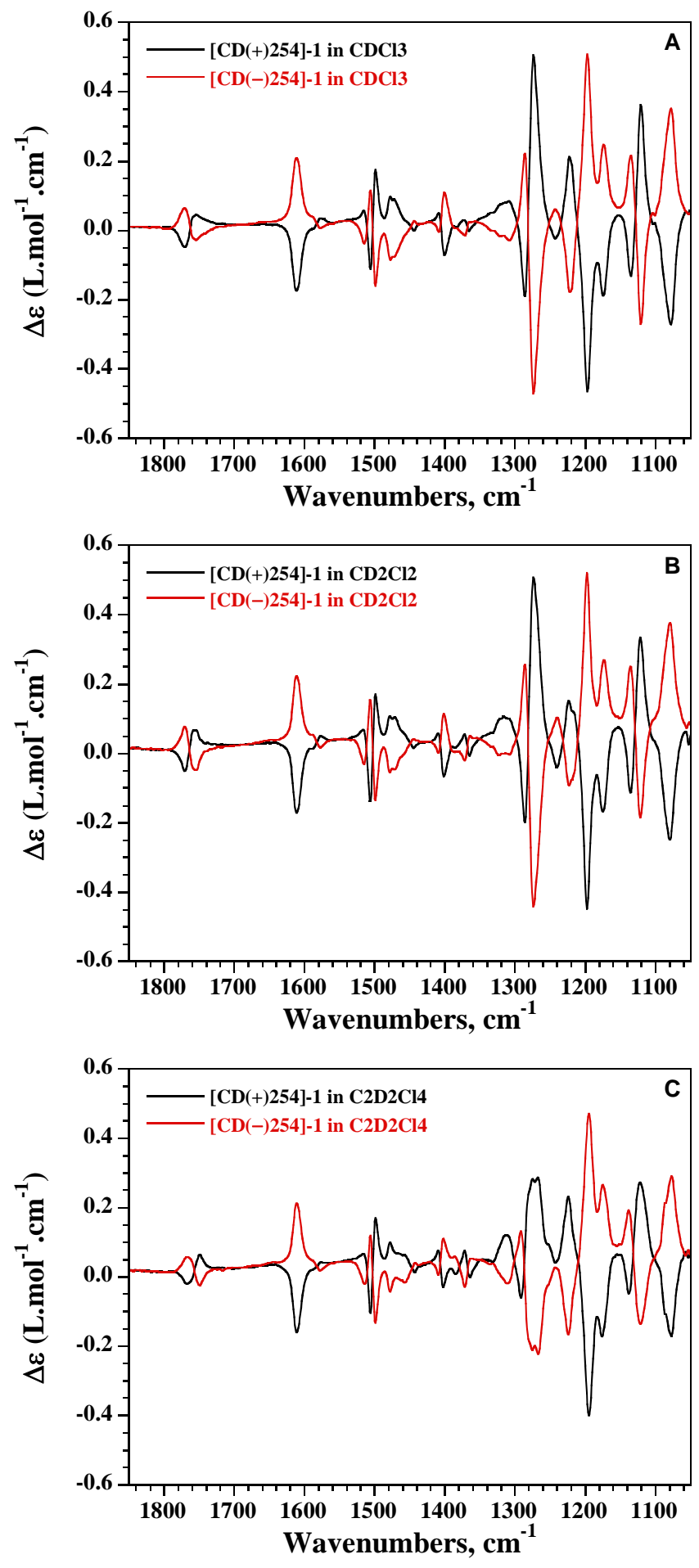

Figure S24: VCD spectra of [CD(+ $\left.)_{254}\right]-\mathbf{1}$ (black spectra) and [CD(- $\left.)_{254}\right]-\mathbf{1}$ (red spectra) in a) $\mathrm{CDCl}_{3}$, b) $\mathrm{CD}_{2} \mathrm{Cl}_{2}$, and c) $\mathrm{C}_{2} \mathrm{D}_{2} \mathrm{Cl}_{4}$ solvents $(0.015 \mathrm{mM}, 250 \mu \mathrm{m}$ path length). 

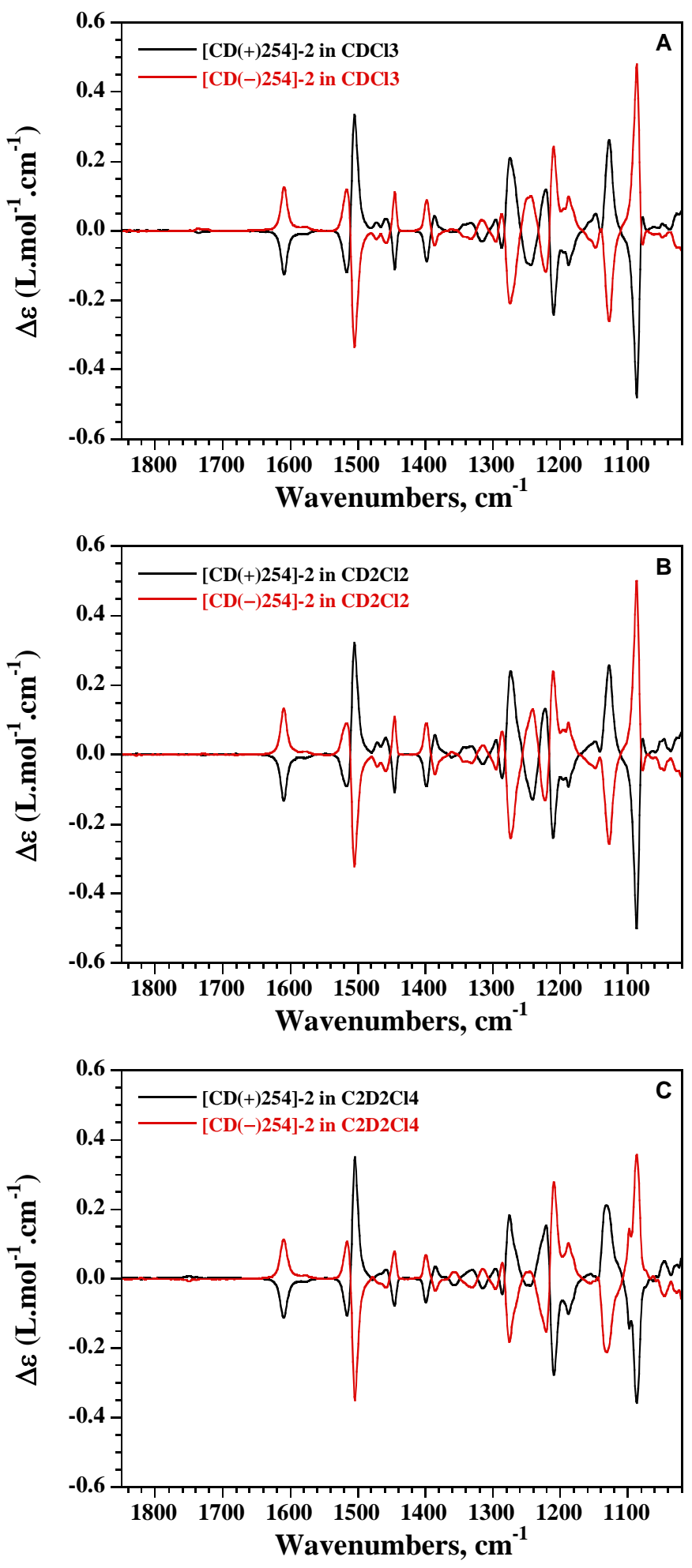

Figure S25: VCD spectra of $\left[\mathrm{CD}(+)_{254}\right]-2$ (black spectra) and [CD(- $\left.)_{254}\right]-2$ (red spectra) in a) $\mathrm{CDCl}_{3}$, b) $\mathrm{CD}_{2} \mathrm{Cl}_{2}$, and c) $\mathrm{C}_{2} \mathrm{D}_{2} \mathrm{Cl}_{4}$ solvents $(0.015 \mathrm{mM}, 250 \mu \mathrm{m}$ path length). 

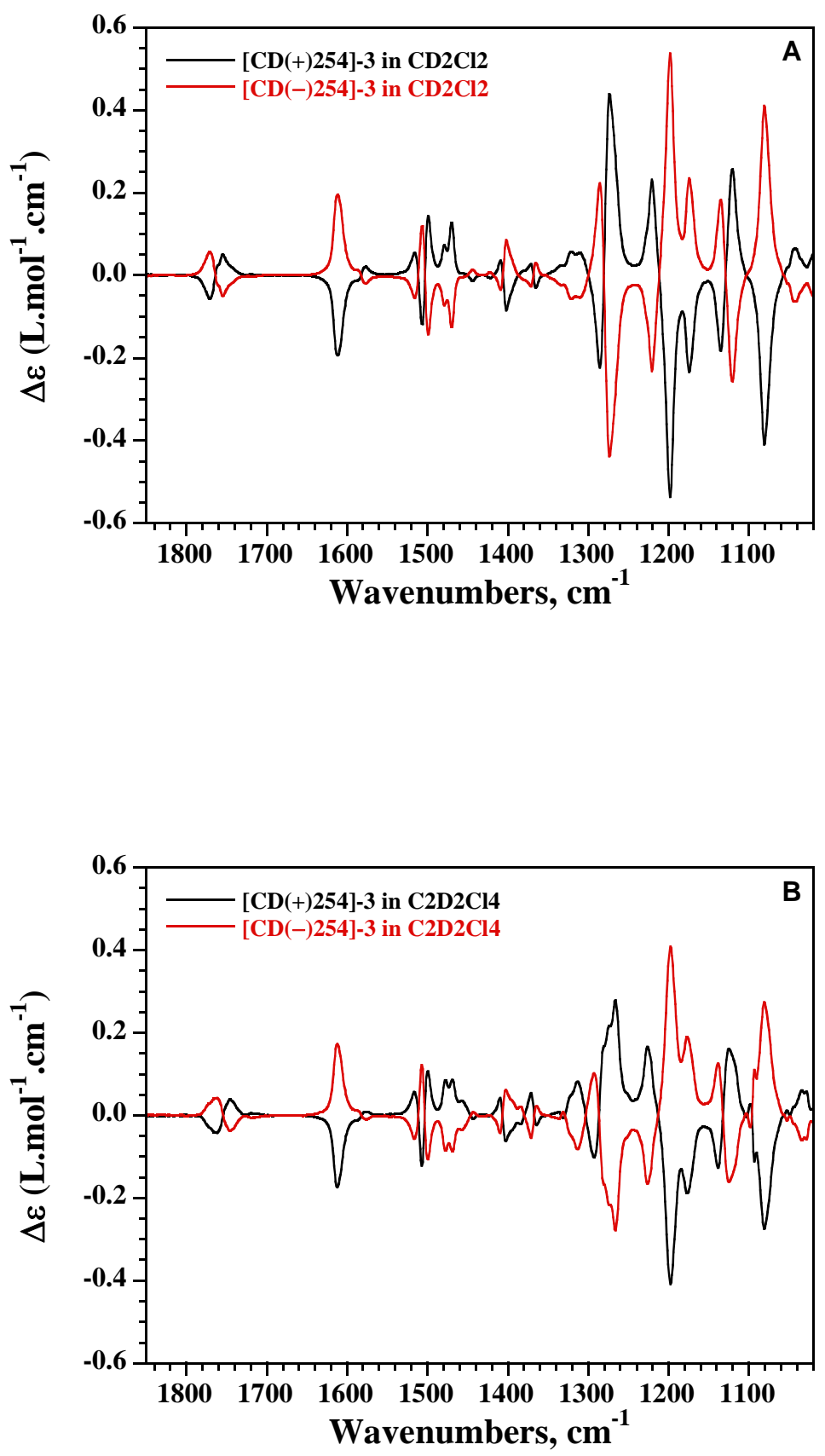

Figure S26: VCD spectra of [CD(+ $\left.)_{254}\right]-3$ (black spectra) and [CD(- $\left.)_{254}\right]-3$ (red spectra) in a) $\mathrm{CD}_{2} \mathrm{Cl}_{2}$ and b) $\mathrm{C}_{2} \mathrm{D}_{2} \mathrm{Cl}_{4}$ solvents ( $0.015 \mathrm{mM}, 250 \mu \mathrm{m}$ path length). 
a) Optimized structure of PP-1: (IEFPCM $\left.=\mathrm{CH}_{2} \mathrm{Cl}_{2}\right)$

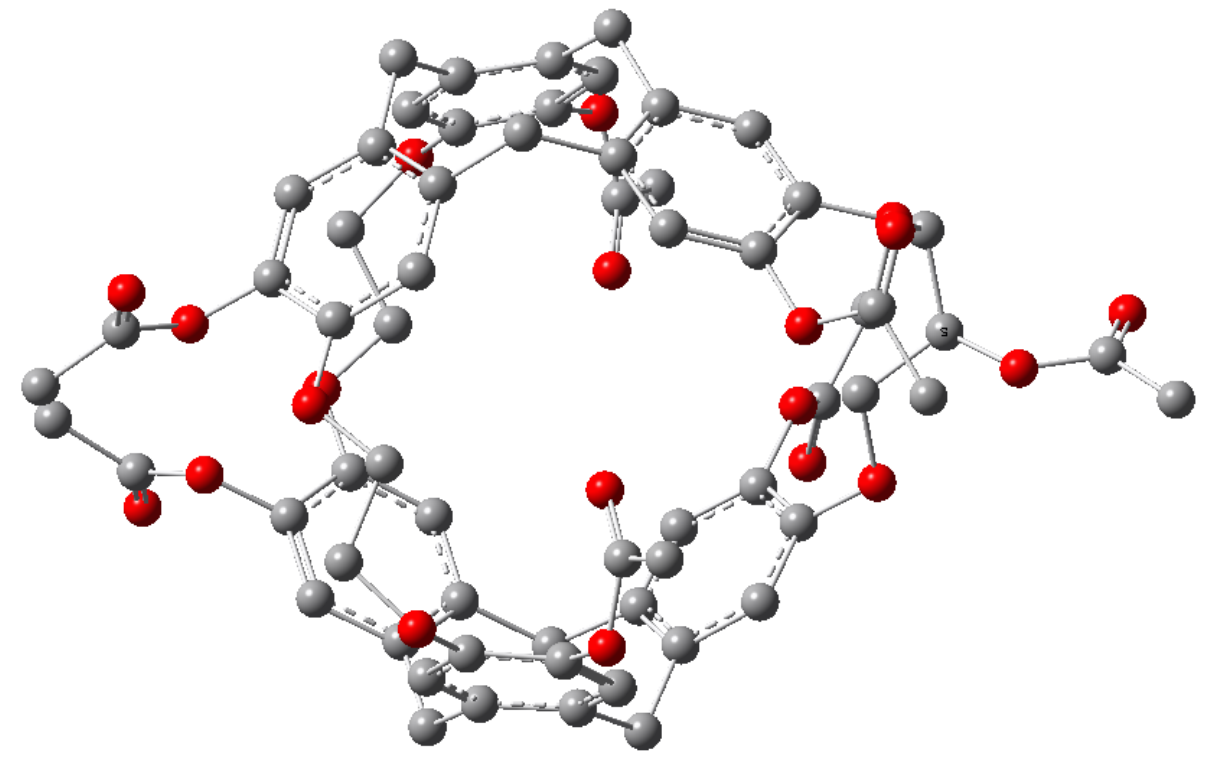

b) Optimized structure of PP-1: (IEFPCM $\left.=\mathrm{C}_{2} \mathrm{H}_{2} \mathrm{Cl}_{4}\right)$

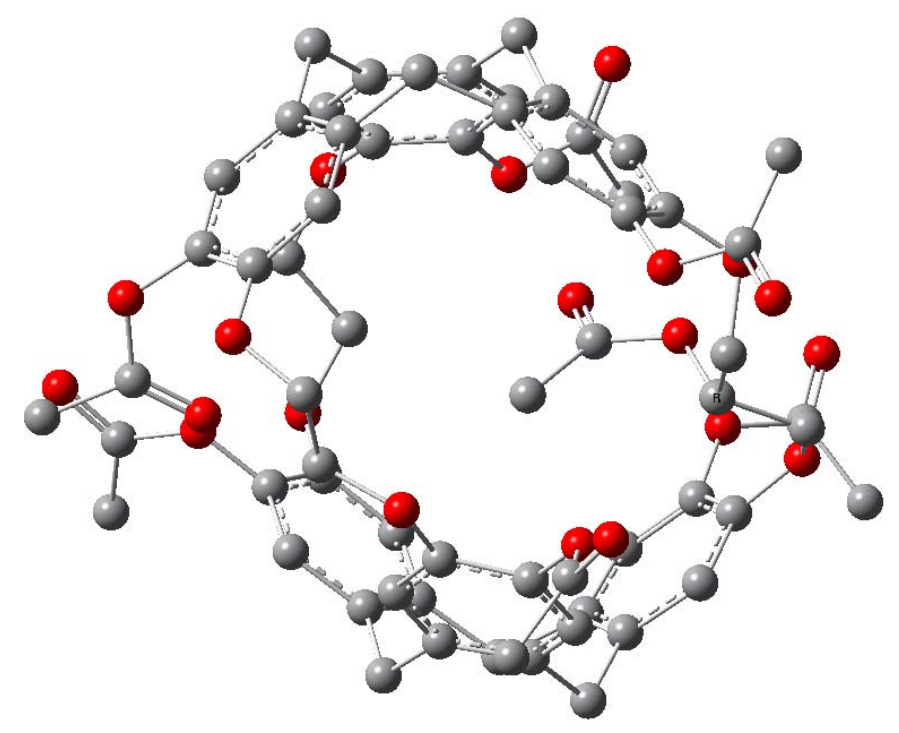

Figure S27: Optimized geometry of $P P-1$ enantiomer calculated at the density functional theory (DFT) level using B3LYP functional and 6-31G** basis set with the use of IEFPCM model of solvent (IEFPCM $=\mathrm{CH}_{2} \mathrm{Cl}_{2}$ and $\mathrm{C}_{2} \mathrm{H}_{2} \mathrm{Cl}_{4}$ ). 
a) Optimized structure of $M M-2$ : $\left(\right.$ IEFPCM $\left.=\mathrm{CH}_{2} \mathrm{Cl}_{2}\right)$

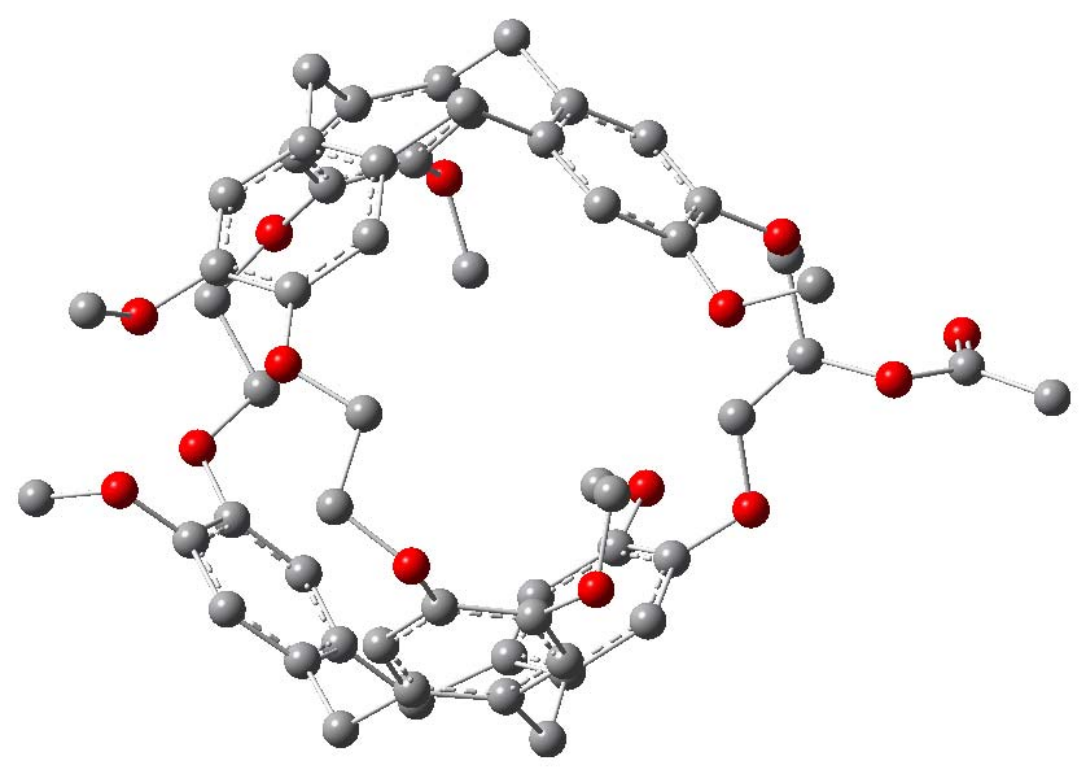

b) Optimized structure of $M M-2$ : (IEFPCM $=\mathrm{C}_{2} \mathrm{H}_{2} \mathrm{Cl}_{4}$ )

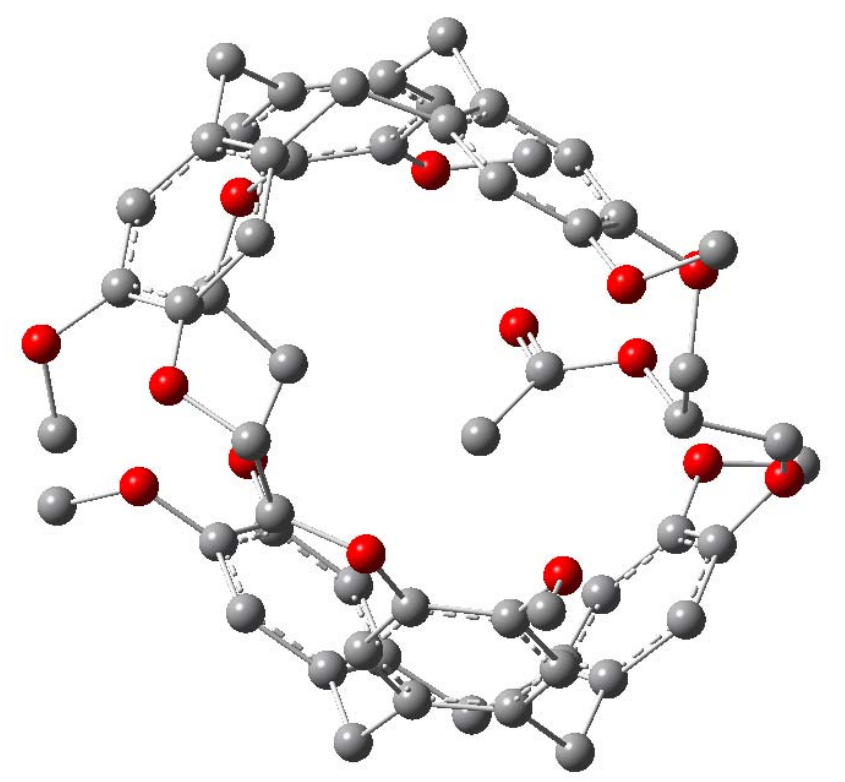

Figure S28: Optimized geometry of $M M-2$ enantiomer calculated at the density functional theory (DFT) level using B3LYP functional and 6-31G** basis set with the use of IEFPCM model of solvent (IEFPCM $=\mathrm{CH}_{2} \mathrm{Cl}_{2}$ and $\mathrm{C}_{2} \mathrm{H}_{2} \mathrm{Cl}_{4}$ ). 


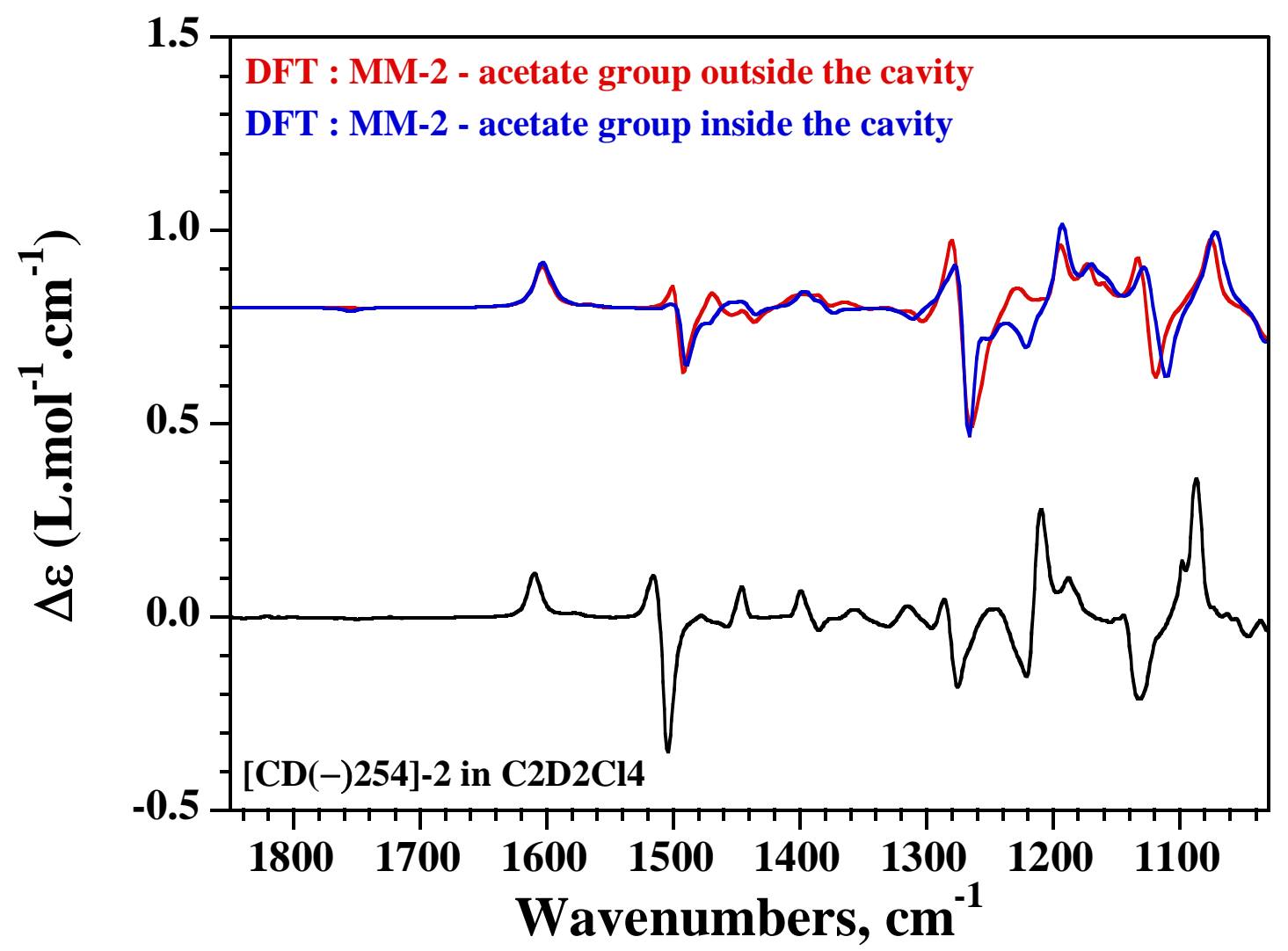

Figure S29: Comparison of experimental VCD spectrum of [CD(- $\left.)_{254}\right]-2$ in $\mathrm{C}_{2} \mathrm{D}_{2} \mathrm{Cl}_{4}$ solution (15 mM, $250 \mu \mathrm{m}$ path length) and VCD spectra of $M M-2$ calculated at the B3LYP/6-31G** level (IEFPCM $=\mathrm{C}_{2} \mathrm{H}_{2} \mathrm{Cl}_{4}$ ) for the trans and gauche-gauche conformations of the ethylenedioxy and propylenedioxy linkers, respectively, and for the acetate group grafted on the propylenedioxy linker pointing inside (blue spectrum) or outside (red spectrum) the cavity. 
Table S1: Specific optical rotation values measured for $\left[\mathrm{CD}(+)_{254}\right]-\mathbf{1}$ in different solvents at $25{ }^{\circ} \mathrm{C}$.

\begin{tabular}{ccccccc}
\hline Solvent & Conc. & {$[\alpha]_{589}$} & {$[\alpha]_{577}$} & {$[\alpha]_{546}$} & {$[\alpha]_{435}$} & {$[\alpha]_{365}$} \\
$\mathrm{CH}_{2} \mathrm{Cl}_{2}$ & 0.21 & -60.1 & -62.3 & -70.3 & -123.4 & -190.9 \\
$\mathrm{CHCl}_{3}$ & 0.23 & -25.4 & -28.3 & -32.1 & -48.5 & -59.8 \\
$\mathrm{DMSO}$ & 0.26 & +7.2 & +7.0 & +8.0 & +19.9 & +61.4 \\
$\mathrm{C}_{2} \mathrm{H}_{2} \mathrm{Cl}_{4}$ & 0.26 & +8.1 & +9.1 & +12.0 & +23.4 & +66.3 \\
\hline
\end{tabular}

Table S2: Specific optical rotation values measured for $\left[\mathrm{CD}(-)_{254}\right]-\mathbf{1}$ in different solvents at $25{ }^{\circ} \mathrm{C}$.

\begin{tabular}{ccccccc}
\hline Solvent & Conc. & {$[\alpha]_{589}$} & {$[\alpha]_{577}$} & {$[\alpha]_{546}$} & {$[\alpha]_{435}$} & {$[\alpha]_{365}$} \\
$\mathrm{CH}_{2} \mathrm{Cl}_{2}$ & 0.21 & +58.4 & +62.0 & +70.3 & +121.2 & +188.2 \\
$\mathrm{CHCl}_{3}$ & 0.25 & +23.9 & +24.9 & +28.4 & +46.9 & +57.3 \\
$\mathrm{DMSO}$ & 0.26 & -7.6 & -8.9 & -9.7 & -23.4 & -66.1 \\
$\mathrm{C}_{2} \mathrm{H}_{2} \mathrm{Cl}_{4}$ & 0.29 & -10.4 & -9.8 & -13.6 & -26.2 & -64.4 \\
\hline
\end{tabular}

Table S3: Specific optical rotation values measured for $\left[\mathrm{CD}(+)_{254}\right]-2$ in different solvents at $25{ }^{\circ} \mathrm{C}$.

\begin{tabular}{|c|c|c|c|c|c|}
\hline Solvent & Conc. & {$[\alpha]_{577}$} & {$[\alpha]_{546}$} & {$[\alpha]_{435}$} & {$[\alpha]_{365}$} \\
\hline $\mathrm{CH}_{2} \mathrm{Cl}_{2}$ & 0.19 & $+159.0+168.0$ & +194.5 & +359.0 & +664.5 \\
\hline $\mathrm{CHCl}_{3}$ & 0.26 & $+201.0+214.1$ & +246.5 & +453.5 & +845.1 \\
\hline DMSO & 0.31 & $+228.3+241.1$ & +278.8 & +510.4 & +943.5 \\
\hline $\mathrm{C}_{2} \mathrm{H}_{2} \mathrm{Cl}_{4}$ & 0.21 & $+199.0+213.0$ & +244.5 & +448.0 & +835.5 \\
\hline
\end{tabular}

Table S4: Specific optical rotation values measured for $\left[\mathrm{CD}(-)_{254}\right]-2$ in different solvents at $25{ }^{\circ} \mathrm{C}$.

\begin{tabular}{ccccccc}
\hline Solvent & Conc. & {$[\alpha]_{589}$} & {$[\alpha]_{577}$} & {$[\alpha]_{546}$} & {$[\alpha]_{435}$} & {$[\alpha]_{365}$} \\
$\mathrm{CH}_{2} \mathrm{Cl}_{2}$ & 0.24 & -155.0 & -163.0 & -189.0 & -347.0 & -652.0 \\
$\mathrm{CHCl}_{3}$ & 0.27 & -200.2 & -211.0 & -245.0 & -446.4 & -823.4 \\
$\mathrm{DMSO}$ & 0.30 & -227.8 & -239.0 & -276.4 & -505.0 & -936.0 \\
$\mathrm{C}_{2} \mathrm{H}_{2} \mathrm{Cl}_{4}$ & 0.20 & -192.5 & -206.0 & -236.5 & -440.5 & -820.0 \\
\hline
\end{tabular}


Table S5: Specific optical rotation values measured for $\left[\mathrm{CD}(+)_{254}\right]-3$ in different solvents at $25{ }^{\circ} \mathrm{C}$.

\begin{tabular}{ccccccc}
\hline Solvent & Conc. & {$[\alpha]_{589}$} & {$[\alpha]_{577}$} & {$[\alpha]_{546}$} & {$[\alpha]_{435}$} & {$[\alpha]_{365}$} \\
$\mathrm{CH}_{2} \mathrm{Cl}_{2}$ & 0.26 & -66.0 & -70.1 & -78.7 & -131.6 & -191.3 \\
$\mathrm{CHCl}_{3}$ & 0.24 & -38.6 & -40.9 & -47.3 & -74.5 & -90.4 \\
$\mathrm{DMSO}$ & 0.25 & -50.0 & -52.9 & -60.5 & -101.5 & -145.0 \\
$\mathrm{DMF}$ & 0.27 & -53.9 & -54.8 & -61.8 & -102.6 & -142.3 \\
$\mathrm{C}_{2} \mathrm{H}_{2} \mathrm{Cl}_{4}$ & 0.30 & -38.9 & -38.3 & -45.7 & -75.6 & -112.7 \\
\hline
\end{tabular}

Table S6: Specific optical rotation values measured for $\left[\mathrm{CD}(-)_{254}\right]-3$ in different solvents at $25{ }^{\circ} \mathrm{C}$.

\begin{tabular}{ccccccc}
\hline Solvent & Conc. & {$[\alpha]_{589}$} & {$[\alpha]_{577}$} & {$[\alpha]_{546}$} & {$[\alpha]_{435}$} & {$[\alpha]_{365}$} \\
$\mathrm{CH}_{2} \mathrm{Cl}_{2}$ & 0.25 & +62.8 & +64.5 & +72.9 & +122.0 & +176.8 \\
$\mathrm{CHCl}_{3}$ & 0.29 & +35.2 & +38.0 & +42.3 & +68.0 & +82.5 \\
$\mathrm{DMSO}$ & 0.26 & +47.0 & +49.0 & +54.8 & +92.2 & +127.5 \\
$\mathrm{DMF}$ & 0.26 & +45.3 & +49.4 & +55.0 & +88.1 & +118.5 \\
$\mathrm{C}_{2} \mathrm{H}_{2} \mathrm{Cl}_{4}$ & 0.31 & +34.0 & +35.1 & +43.9 & +68.2 & +102.0 \\
\hline
\end{tabular}

Table S7: B3LYP/6-31G** frequencies (scaled by 0.968) of the ester $v C=\mathrm{O}$ stretching vibration of $M M-2$ (IEFPCM $=\mathrm{CH}_{2} \mathrm{Cl}_{2}$ and $\mathrm{C}_{2} \mathrm{D}_{2} \mathrm{Cl}_{4}$ ) for the acetate group pointing inward or outward the cavity.

\begin{tabular}{ccc}
\hline & IEFPCM $=\mathrm{CH}_{2} \mathrm{Cl}_{2}$ & IEFPCM $=\mathrm{C}_{2} \mathrm{D}_{2} \mathrm{Cl}_{4}$ \\
\hline $\begin{array}{c}\text { Acetate pointing inward the } \\
\text { cavity }\end{array}$ & 1753.58 & 1755.17 \\
$\begin{array}{c}\text { Acetate pointing outward the } \\
\text { cavity }\end{array}$ & 1741.42 & 1742.52 \\
\hline
\end{tabular}


Full list of authors of references 25

25 Frisch, M. J.; Trucks, G. W.; Schlegel, H. B.; Scuseria, G. E.; Robb, M. A.; Cheeseman, J. R.; Scalmani, G.; Barone, V.; Mennucci, B.; Petersson, G. A.; Nakatsuji, H.; Caricato, M.; Li, X.; Hratchian, H. P.; Izmaylov, A. F.; Bloino, J.; Zheng, G.; Sonnenberg, J. L.; Hada, M.; Ehara, M.; Toyota, K.; Fukuda, R.; Hasegawa, J.; Ishida, M.; Nakajima, T.; Honda, Y.; Kitao, O.; Nakai, H.; Vreven, T.; Montgomery, Jr., J. A.; Peralta, J. E.; Ogliaro, F.; Bearpark, M.; Heyd, J. J.; Brothers, E.; Kudin, K. N.; Staroverov, V. N.; Kobayashi, R.; Normand, J.; Raghavachari, K.; Rendell, A.; Burant, J. C.; Iyengar, S. S.; Tomasi, J.; Cossi, M.; Rega, N.; Millam, N. J.; Klene, M.; Knox, J. E.; Cross, J. B.; Bakken, V.; Adamo, C.; Jaramillo, J.; Gomperts, R.; Stratmann, R. E.; Yazyev, O.; Austin, A. J.; Cammi, R.; Pomelli, C.; Ochterski, J. W.; Martin, R. L.; Morokuma, K.; Zakrzewski, V. G.; Voth, G. A.; Salvador, P.; Dannenberg, J. J.; Dapprich, S.; Daniels, A. D.; Farkas, Ö.; Foresman, J. B.; Ortiz, J. V.; Cioslowski, J.; Fox, D. J. Gaussian 09, revision A.1, Gaussian Inc., Wallingford CT, 2009. 